\title{
軸力と曲げおよびねじりを受ける薄肉断面部材 \\ THIN-WALLED MEMBERS UNDER AXIAL FORCE, BENDING AND TORSION
}

\author{
西野文雄* ・倉方慶夫** ・長谷川彰夫*** ・ 奥 村 敏 恵***** \\ By Fumio Nishino, Yoshio Kurakata, Akio Hasegawa and Toshie Okumura
}

\section{1.まえがき}

薄肉直線棒部材の有限変位理論に基づく研究は, 主と して座屈問題に関連して, 多くの研究者の注目を集めて きた。これらの研究のうち, 軸方向力, 二主軸回りの曲 げモーメント, ねじりモーメントの作用する, もっとも 一般的な荷重状態についてのつり合い式を求めた結果が Vlasov $^{1)}$, Roik, Carl, Lindner ${ }^{2)}$, 坂井 ${ }^{3)}$ によって報告 されている。Vlasov および Roik, Carl, Lindner の両 者とも, 棒部材に生じている応力場, 変位場を, ともに 線形化し, その応力場に対して変位時の幾何学的考察を 加えてつり合いの微分方程式を求めている。坂井は初期 忘力゙) の概念を用いて, エネルギ一原理からつり合い式 を求めている。このとき, 初期応力場, および変位場と して，前者と同じく線形化したものが用いられている。 これら 3 つの報告に示されている結果にはそれぞれ多少 の差がみられるが，いずれもいわゆる線形化有限変位理 論に属するものである。しかしながら, 応力場, 変位場 を, はじめから線形化して与えているために, 線形化有 限変位理論としても, 必ずしも十分なものではなく, 固 有值問題に限っても適用範囲に制約が生じる。その一つ の例をはり，あるいは柱一はりの横座屈の問題にみるこ とができる。二主軸に関して対称な断面の，いわゆる弱 軸回りに曲げモーメントが作用しているはりに横座屈現 象が生じることは考え難く, 事実横座屈現象が生じない という研究成果も報告されている5 (6)。これに反し, 前 記の 理論に基ゔくと, 弱軸まわりに作用している曲げ モーメントがある值になると, つり合い系が唯一でなく なり，横方向に座屈した状態でもつり合い状態が存在す

* 正 会員 Ph. D. 東京大学助教授 工学部綜合試験所

** 学生会員 工修 東京大学大学院博士課程在学

*** 正 会 員 工博 名古屋工業大学講師 土木工学科

**** 正 会 員 工博 東京大学教授 工学部土木工学科
る結果が得られる。

薄肉直線棒部材のより一般的な有限変位理論に基 づく支配方程式を, 仮想仕事の原理より求めたものに Nishino, Kasemset, Lee $\left.{ }^{6}\right)$ の研究がある。幾何学的な 考察からつり合い式を求めるとき, 力の大きさ, 向き, 方向に十分な注意を払わなければならないのに対し，仮 想仕事の原理に基づくと, 変位場を仮定すれば, すべて の支配式が数学的な演算のみで求まる。このこレから， 後者によって求められた支配方程式の精度は, す心゙て変 位場の仮定によって決まり，したがって，理論展開にあ たって変位場に対する検討がもっとも重要となる。ここ では, Nishino, Kasemset, Lee による研究の変位場に 対する検討に, さらに吟味を加え, 発展させた薄肉直線 棒部材の支配方程式について報告する。

棒部材に適用される一次元の変位場を求めるために, 三次元問題に対して得られているひずみ-変位の関係を, 従来から棒理論で用いられているのと同じ仮定を用い て, 一次元の関係に変換する。このために, 次の 4 つを 仮定する。

（i ） 断面寸法に比べ, 部材長は十分に長く, 部材軸 方向の変位の微係数は比較的小さい。

(ii ) 断面は変形しない。

(iii) 薄板要素の板厚中心面に垂直で, 部材軸線に平 行な面内でのせん断ひずみは小さく，無視し得る。

(iv) 板厚中心面内のせん断ひずみのうち, 直応力や 分布外力とつり合い状態にあるせん断応力によるせん断 ひずみは小さく，無視し得る。これはオイラー・ベル ヌーイの平面保持の仮定を拡張したものである。

棒理論では, 部材軸方向の直応力に比べて, これに直 交する方向の直応力は小さく, したがって, 部材軸方向 の直応力と直ひずみは弾性係数を定数とする比例関倸に ある，とする仮定が一般に用いられている。この報告で も一次元の直応力-直ひずみ関係として, この関係を仮 定する。 


\section{2.ひずみと変位の関係}

薄肉断面の一例を Fig. 1 に示す。この報告では部材 上の点を表わすのに 2 組の物体固定座標系を用い, ラ グランジュの方法を採用する。その一つは任意点 $C$ を 原点とする $(x, y, z)$ 座禋であり, 基準状態（変形前） では, デカルト座標を構成する。他の一つは $(s, n, z)$ 座標であり, 基準状態では直交曲線座標である。ここに $s$ は断面の板厚中心線に沿ってとった座標であり，その 中心線上の任意点 0 汇原点をもつ。また $n$ は板厚中心 線を原点とし，これ江垂直な座標である。両座標系に共 通な $z$ 座標を, 部材槙汇平行汇選ぶ。両座標系ともに在 手系の座標とする

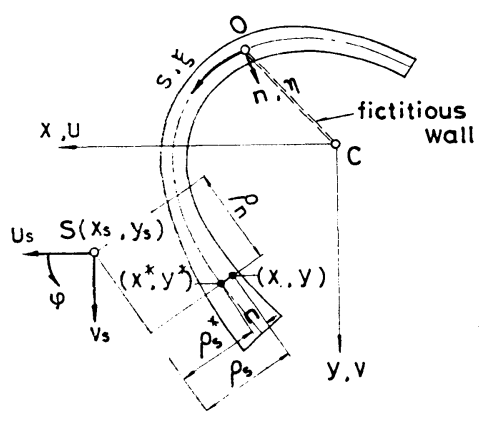

Fig. 1 Coordinates and Reference Points

有限変位理論によるびずみ-変位の関倸は, ラグラン ジュの方法を用い，基準状態がデカルト座標を構成する とき，次式で表わさ礼る゙ 。

$$
\begin{aligned}
& \epsilon_{x}=\frac{\partial u}{\partial x}+\frac{1}{2}\left\{\left(\frac{\partial u}{\partial x}\right)^{2}+\left(\frac{\partial v}{\partial x}\right)^{2}+\left(\frac{\partial w}{\partial x}\right)^{2}\right\} \\
& \epsilon_{y}=\frac{\partial v}{\partial y}+\frac{1}{2}\left\{\left(\frac{\partial u}{\partial y}\right)^{2}+\left(\frac{\partial v}{\partial y}\right)^{2}+\left(\frac{\partial w}{\partial y}\right)^{2}\right\} \\
& \epsilon_{z}=\frac{\partial w}{\partial z}+\frac{1}{2}\left\{\left(\frac{\partial u}{\partial z}\right)^{2}+\left(\frac{\partial v}{\partial z}\right)^{2}+\left(\frac{\partial w}{\partial z}\right)^{2}\right\} \\
& 2_{r_{x y}}=\frac{\partial v}{\partial x}+\frac{\partial u}{\partial y}+\frac{\partial u}{\partial x} \cdot \frac{\partial u}{\partial y}+\frac{\partial v}{\partial x} \cdot \frac{\partial v}{\partial y} \\
& +\frac{\partial w}{\partial x} \cdot \frac{\partial w^{\prime}}{\partial y} \\
& 2 \gamma_{y z}=\frac{\partial w}{\partial y}+\frac{\partial \tilde{c}}{\partial z}+\frac{\partial u}{\partial y} \cdot \frac{\partial u}{\partial z}+\frac{\partial v}{\partial y} \cdot \frac{\partial v}{\partial z} \\
& +\frac{\partial w}{\partial y} \cdot \frac{\partial r}{\partial z} \\
& 2 \gamma_{z x}=\frac{\partial u}{\partial z}+\frac{\partial z \dot{v}}{\partial x}-\frac{\partial u}{\partial z} \cdot \frac{\partial u}{\partial x}+\frac{\partial v}{\partial z} \cdot \frac{\partial v}{\partial x} \\
& +\frac{\partial w}{\partial z} \cdot \frac{\partial w}{\partial x}
\end{aligned}
$$

ここに, $\epsilon_{x}, \epsilon_{y}, \epsilon_{z}, r_{x y}, \tau_{y z}, \gamma_{z x}$ はひずみテンソルの成 分であり, $u, v, w$ はそれぞれ基準状態での $x, y, z$ 方
向への変位である。

仮定 (i) から, 式 (2.1) 中の w の微倸数は他に比べ 小さいものとし， $w$ の微倸数の 2 次項を無視する。こ れより式 (2.1) は

$$
\begin{aligned}
\epsilon_{x} & =\frac{\partial u}{\partial x}+\frac{1}{2}\left\{\left(\frac{\partial u}{\partial x}\right)^{2}+\left(\frac{\partial v}{\partial x}\right)^{2}\right\} \cdots \cdots \\
\epsilon_{y} & =\frac{\partial v}{\partial y}+\frac{1}{2}\left\{\left(\frac{\partial u}{\partial y}\right)^{2}-\left(\frac{\partial v}{\partial y}\right)^{2}\right\} \cdots \cdots \\
\epsilon_{z} & =\frac{\partial w}{\partial z}+\frac{1}{2}\left\{\left(\frac{\partial u}{\partial z}\right)^{2}+\left(\frac{\partial v}{\partial z}\right)^{2}\right\} \cdots \cdots \\
2 r_{x y} & =\frac{\partial v}{\partial x}+\frac{\partial u}{\partial y}+\frac{\partial u}{\partial x} \cdot \frac{\partial u}{\partial y}+\frac{\partial v}{\partial x} \cdot \frac{\partial v}{\partial y} \\
2 r_{y z} & =\frac{\partial w}{\partial y}+\frac{\partial v}{\partial z}+\frac{\partial u}{\partial y} \cdot \frac{\partial u}{\partial z}+\frac{\partial v}{\partial y} \cdot \frac{\partial v}{\partial z} \\
2 r_{z x} & =\frac{\partial u}{\partial z}+\frac{\partial w}{\partial x}+\frac{\partial u}{\partial z} \cdot \frac{\partial u}{\partial x}+\frac{\partial v}{\partial z} \cdot \frac{\partial v}{\partial x}
\end{aligned}
$$

仮定（ii）を数式で表わすとひずみに関して

$$
\epsilon_{x}=0, \epsilon_{y}=0, r_{x y}=0 \cdots
$$

と書くことができる。断面の㴊体変位に効する幾何学的 条件を考えると変位 $u, v$ は次のように表わされ，その 変位は式 (2.2 a, b , d) を式 (2.3) に代入した微分方程 式を満足し，したがってこの式の解となっている。

$$
\begin{array}{r}
u=u_{s}-\left(y-y_{s}\right) \sin \varphi-\left(x-x_{s}\right)(1-\cos \varphi) \\
\cdots \ldots \ldots \ldots \ldots \ldots \cdots \cdots \cdots \cdots \cdots \cdots \cdots(2 . \\
v=v_{s}+\left(x-x_{s}\right) \sin \varphi-\left(y-y_{s}\right)(1-\cos \varphi)
\end{array}
$$

ここに, $u_{s}, v_{s}, \varphi$ は積分定数であり， $u_{s}, v_{s}$ はそれぞ れ任意点 $S\left(x_{s}, y_{s}\right)$ の $x, y$ 方向の変位を, $\varphi$ は同じ点 での回転変位を表わす。

方向余弦 $l, m$ を

$$
l=\cos (s, x), m=\cos \left(s, y^{\prime}\right) \cdots
$$

と定義すると, 基準状態での $s, n$ 方向への変位 $\xi, \eta$ は これらを用いて次のように表わされる。

$$
\begin{aligned}
& \xi=l u+m v=l u_{s}+m v_{s}+\rho_{s} \sin \varphi \\
& -\rho_{n}(1-\cos \varphi) \\
& \eta=-m u+l v=-m u_{s}+l v_{s}+\rho_{n} \sin \varphi \\
& +\rho_{s}(1-\cos \varphi)
\end{aligned}
$$

$こ こ に$

$$
\left.\begin{array}{l}
\rho_{s}=m\left(x-x_{s}\right)-l\left(y-y_{s}\right) \\
\rho_{n}=l\left(x-x_{s}\right)+m\left(y-y_{s}\right)
\end{array}\right\}
$$

薄肉中心線上 $(n=0)$ での諸星を（）*で表わすと， 断面上の一般の点の $x, y$ 座標は中心線上の $x, y$ 座標, すなわち, $\left(x^{*}, y^{*}\right)$ と $n$ 座標を用いて

$$
x=x^{*}-m n, y=y^{*}+\ln
$$

と表わしうる。 $\rho_{s}, \rho_{n}$ については

$$
\rho_{s}=\rho_{s}^{*}-n, \rho_{n}=\rho_{n} *
$$


の関係がある。

せん断ひずみに関する仮定を用いるために，式 (2.2) の $r_{x z}, \gamma_{y z}$ を $(s, n, z)$ 座標に関するせん断ひずみ $\gamma_{s z}$, $\gamma_{n z}$ に変換する。直交座標間での座標変換を行うことに よって,

$$
\begin{aligned}
2 \gamma_{s z} & =2\left(m \gamma_{y z}+l \gamma_{z x}\right) \\
& =\frac{\partial \xi}{\partial z}+\left(\frac{\partial w}{\partial s}+\frac{\partial u}{\partial z} \cdot \frac{\partial u}{\partial s}+\frac{\partial v}{\partial z} \cdot \frac{\partial v}{\partial s}\right) \frac{1}{1-n / r^{*}} \\
& \ldots \ldots \ldots \cdots \cdots \cdots \cdots \cdots(2.10 \mathrm{a}) \\
2 \gamma_{n z} & =2\left(l_{\gamma_{y z}}-m \gamma_{z x}\right) \\
& =\frac{\partial \eta}{\partial z}+\frac{\partial w}{\partial n}+\frac{\partial u}{\partial z} \cdot \frac{\partial u}{\partial n}+\frac{\partial v}{\partial z} \cdot \frac{\partial v}{\partial n}
\end{aligned}
$$

を得る注 1)。ここに $n$ 座標の方向に曲率の中心がある場合 $r^{*}>0$ とする。 仮定 (iii) は

$$
r_{n z}=0 \text {. }
$$

と書ける。式 $(2.4),(2.6 \mathrm{~b})$ を式 $(2.10 \mathrm{~b})$ に代入し， 式 (2.11) の関係を用いて $n$ について積分すると,

$$
\begin{aligned}
w= & w^{*}+\left\{m\left(u_{s}^{\prime} \cos \varphi+v_{s}^{\prime} \sin \varphi\right)\right. \\
& \left.-l\left(v_{s}^{\prime} \cos \varphi-u_{s}^{\prime} \sin \varphi\right)-\rho_{n} \varphi^{\prime}\right\} n \cdots
\end{aligned}
$$

ここに, $w^{*}$ は積分定数であり, $(s, n=0, z)$ での $z$ 方 向への変位を表わす。（ ）'は $z$ に関する微分を表わす。

仮定（iv）のオイラー・ベルヌイの仮定から，開断面 あるいは断面の分岐部のうら開いた部分（以下開区間と よぶ）に対しては, 薄肉の前提により板厚中心面のせん 断ひずみ $\gamma_{s z}{ }^{*}$ は

$$
r_{s} z^{*}=0
$$

と表わせる。閉断面あるいは閉断面部（以下闒区間とよ ぶ）に対しては， $r_{s z}{ }^{*}$ を 0 とおくと，一般には断面の $z$ 方向の変位にくい違いを生ずる。仮定（iv）を閉区間 に適用するために, 微少要素 $t d s d z$ のつり合いを考え

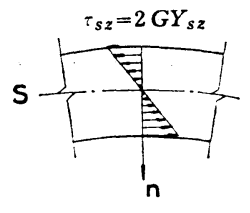

(a)

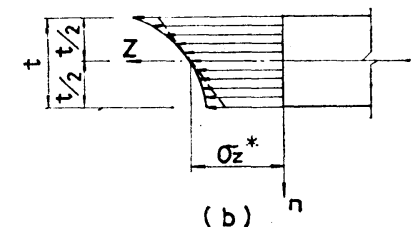

(b)
Fig. 2 Stress Distribution across Thin Wall : (a) Shear Stress; (b) Normal Stress

注 1) 式 (2.5) の方向余弦 $l, m$ は板厚中心線上で

$$
l^{*}=\frac{\partial x^{*}}{\partial s}=-\frac{\partial y}{\partial n}, m^{*}=\frac{\partial y^{*}}{\partial s}=-\frac{\partial x}{\partial n} \cdots(\mathrm{a})
$$

と表わすことができる。板厚中心線の曲率半径 $r^{*}$ を用 いると, 一般点では

$$
l=\frac{\partial x}{\partial s} \cdot \frac{1}{1-n / r^{*}}, \quad m=\frac{\partial y}{\partial s} \cdot \frac{1}{1-n / r^{*}}
$$

となる。式 (2.10) では上記 (a)，(b) の関係を用いて いる。
る。式 (2.4)，(2.6 a)，(2.12) なよで (2.10a) からせ ん断ひずみ $r_{s z}$ は, Fig. 2 (a) に示すように, 薄肉孛 前提とすると $n$ の一次関数であるここがわかる注 2$) 。 し$ たがって, 板厚中心面上のせん断ひずみ $r_{s z}$ * は $\gamma_{s z}$ の 板厚方向の平均值となっており，せん断応力 $\tau_{s z}$ につい ても同様である。このことを考罳すると， $z$ 方向線素の 変形後の方向のつり合い式は, 直忘力 $\sigma_{z}$ と変形後の部 材軸方向の単位体積あたりの分布外力 $\tilde{p}_{z d}$ および $\tau_{s z}{ }^{*}$ を用いて

$$
\frac{\partial\left(\tau_{\left.s z^{*} t\right)}\right.}{\partial s}+\frac{\partial}{\partial z}\left\{\int_{-t / 2}^{t / 2} \sigma_{z} d n\right\}+\int_{-t / 2}^{t / 2} \tilde{p}_{z d} d n=0
$$

となる。ここに $t$ は板厚である。式 (2.14) を $s$ につ いて積分し, せん断弾性係数 $G$ でわると

$$
\begin{aligned}
& 2 r_{s z} *=\frac{q_{1}}{G t}-\frac{1}{G t} \int_{s_{1}}^{s}\left[\frac{\partial}{\partial z}\left\{\int_{-t / 2}^{t / 2} \sigma_{z} d n\right\}\right. \\
& \left.+\int_{-t / 2}^{t / 2} \tilde{p}_{z d} d n\right] d s
\end{aligned}
$$

ここに, $q_{1}=\left(\tau_{s z}{ }^{*} t\right)_{s=s_{1}}$ は積分定数であり, $s_{1}$ は板厚 中心線上の任意点の $s$ 座標である。仮定 (iv) から式 (2.15) の右辺第 2 項を小さいものレして無視し, 次の ように表わす。

$$
2 \gamma_{s z}{ }^{*}=\frac{q_{1}}{G t}
$$

開区間に対して式 (2.16) を適用する上, 自由縁での条 件から， $q_{1}$ は 0 となる。したがって, 式 (2.13) は式 (2.16) の特殊な場合に相当する。この報告では, 式 (2.16) をオイラー・ベルヌイの仮定を数式化したもの と考える。

式 (2.10a) に式 (2.4)（2.6a）および (2.16) を代 入すると

$$
\begin{aligned}
\frac{\partial w^{*}}{\partial s}= & \frac{q_{1}}{G t}-l\left(u_{s}^{\prime} \cos \varphi-r_{s}^{\prime} \sin \varphi\right) \\
& -m\left(v_{s}^{\prime} \cos \varphi-u_{s}^{\prime} \sin \varphi\right)-\rho_{s}^{*} \varphi^{\prime}
\end{aligned}
$$

閉区間の場合， $q_{1}$ はこの区間でつ変位 $w$ の連続条件

$$
\oint \frac{\partial w^{*}}{\partial s} d s=0
$$

から定まる。ここに $\oint d s は$ 閉区間について一周積分す

注 2)一般の場合厳密には, $\gamma_{s z}$ 流 $\boldsymbol{n}$ の一次関数とはなら ず, 式 (2.10 a) に式 (2.4), (2.6) および (2.12)を代 入すると

$$
\begin{aligned}
& 2 \gamma_{s z}=\frac{1}{1-n / r^{*}}\left[\frac{\partial w^{*}}{\partial s} \div l\left(u_{s}^{\prime} \cos \varphi+v_{s}{ }^{\prime} \sin \varphi\right)\right. \\
& \left.\quad+m\left(v_{s}^{\prime} \cos \varphi-u_{s}^{\prime} \sin \varphi\right)+\rho_{s}^{*} \varphi^{\prime}-n\left(2-\frac{n}{r^{*}}\right) \varphi^{\prime}\right]
\end{aligned}
$$

となる。薄肉の前提を式で表わすと， $|t| r * \mid<1$.

であるから, 薄肉の場合には式 (c) の $n / r^{*}$ の項が無視 でき $\gamma_{s z}$ は $n$ の一次関数と見なせる。 
ることを表わす。以上から， $q_{1}$ は開区間と閉区間に対 し，それ㫕次のように定まる。

$$
q_{1}= \begin{cases}0 & \text { (開区間) } \\ G \frac{\rho_{s}^{*} d s}{\oint \frac{1}{t} d s} \varphi^{\prime} & \text { (閉区間) }\end{cases}
$$

式 (2.17) を $s$ について積分すると

$$
\begin{aligned}
w^{*}= & c(z)-x^{*}\left(u_{s}^{\prime} \cos \varphi+v_{s}^{\prime} \sin \varphi\right) \\
& -y^{*}\left(\tau^{\prime}{ }^{\prime} \cos \varphi-u_{s}^{\prime} \sin \varphi\right)-\Omega^{*} \varphi^{\prime} \cdots(2.20)
\end{aligned}
$$

ここに $c(\approx)$ は積分定数であり, $\Omega^{*}(s)$ は次式で表わさ れる。

$$
\Omega^{*}= \begin{cases}\int_{0}^{s} \rho_{s}^{*} d s & \text { (開区間) } \\ \int_{0}^{s}\left(\rho_{s}^{*}-\frac{\oint \rho_{s}^{*} d s}{\oint \frac{1}{t} d s} \cdot \frac{1}{t}\right) d s \quad \text { (閉区間) }\end{cases}
$$

$x y$ 座標の原点 $C$ を一般の点に選ぶとすると, 点 $C$ は必ずしも板厚中心線上にない。したがって, 変位 を原点 $C$ で定義できなくなる。ここでは便宜上，式 (2.17) の積分定数 $c(\approx)$ を原点 $C$ の変位を用いて表 わすために, 原点 $C$ と $s$ 座標の原点 0 の間を Fig. 1 に示寸ように, 仮想の板厚 $t=0$ の薄板で結ぶ。このよ うにしても $t=0$ であるため, この薄板は棒部材の力学 的性質に影響を与えることはない。この結果, 原点 $C$ の $z$ 軸方向の変位が定義できるようになり, それを $w_{c}=$ $w(x=0, y=0, z)$ と表わすと, 式 (2.20) より積分定数 $c(\approx)$ は $w_{c}$ を用いて次のように表わされる。

$$
c(z)=w_{c}+\Omega_{c}{ }^{*} \varphi^{\prime}
$$

ここに, $\Omega_{c}^{*}$ は原点 $C$ での $\Omega^{*}$ であり, 次のように表 わされる。

$$
\Omega_{c} *=\int_{0}^{s_{c}} \rho_{s} * d s
$$

$s_{c}$ は原点 $C$ の仮想薄板に沿ってはかられる $s$ 座標であ る。式 (2.12)，(2.20) および (2.22) から (i)〜 (iv)の 仮定を満たす $w$ として次式を得る。

$$
\begin{aligned}
w= & w_{c}-x\left(u_{s}^{\prime} \cos \varphi+v_{s}{ }^{\prime} \sin \varphi\right) \\
& -y\left(v_{s}^{\prime} \cos \varphi-u_{s}^{\prime} \sin \varphi\right)-\omega \varphi^{\prime}
\end{aligned}
$$

ここに，

$$
\begin{aligned}
& \int_{z_{1}}^{z_{2}}\left[N^{\prime}+p_{z}\right] \delta w^{\prime} d z-\left[(N-\bar{N}) \delta w_{c}\right]_{z_{1}}^{z_{2}}+\int_{z_{1}}^{z_{2}}\left[\left(M_{x} \cos \varphi-M_{y} \sin \varphi\right)^{\prime \prime}+\left[N\left\{u_{s}^{\prime}+\left(y_{s}^{\prime} \cos \varphi+x_{s} \sin \varphi\right) \varphi^{\prime}\right\}\right]^{\prime}\right. \\
& \left.+p_{x}+\left(m_{x} \cos \varphi-m_{y} \sin \varphi\right)^{\prime}\right] \delta u_{s} d z+\left[\left[\bar{V}_{x}-\left(M_{x} \cos \varphi-M_{y} \sin \varphi\right)^{\prime}-N\left\{u_{s}^{\prime}+\left(y_{s} \cos \varphi+x_{s} \sin \varphi\right) \varphi^{\prime}\right\}\right.\right. \\
& \left.\left.-\left(m_{x} \cos \varphi-m_{y} \sin \varphi\right)\right] \delta u_{s}\right]_{z_{1}}^{z_{2}}+\left[\left[\left(M_{x} \cos \varphi-M_{y} \sin \varphi\right)-\left(\bar{M}_{x} \cos \varphi-\bar{M}_{y} \sin \varphi\right)\right] \delta u_{s}^{\prime}\right]_{z_{1}}^{z_{2}}
\end{aligned}
$$

注 3）これは St. Venant のねじりにおけるせん断ひずみを表わしている。式 $(2.10 \mathrm{a})$ から計算を進めると，

$$
2 \gamma_{s z}=\frac{\theta+n^{2} / r^{*}}{1-n / r^{*}} \varphi^{\prime}
$$

となる。脚注 2) の式 (d) の薄肉の前提条件式を用いると式 (e) は, 式 $(2.26$ b) となる。式 $(2.10 \mathrm{a})$ の段階で薄肉の 条件を用いると St. Venant のねじれを表わす式 $(2.26$ b) 式を得ることができないことに注意しなければならない。 
$+\int_{z_{1}}^{z_{2}}\left[\left(M_{y} \cos \varphi+M_{x} \sin \varphi\right)^{\prime \prime}+\left[N\left\{v_{s}^{\prime}-\left(x_{s} \cos \varphi-y_{s} \sin \varphi\right) \varphi^{\prime}\right\}\right]^{\prime}+p_{y}+\left(m_{y} \cos \varphi+m_{x} \sin \varphi\right)^{\prime}\right] \delta v_{s} d z$ $+\left[\left[\bar{V}_{y}-\left(M_{y} \cos \varphi+M_{x} \sin \varphi\right)^{\prime}-N\left\{v_{s}^{\prime}-\left(x_{s} \cos \varphi-y_{s} \sin \varphi\right) \varphi^{\prime}\right\}-\left(m_{y} \cos \varphi+m_{x} \sin \varphi\right)\right] \delta v_{s}\right]_{z_{1}}^{z_{2}}$ $+\left[\left\{\left(M_{y} \cos \varphi+M_{x} \sin \varphi\right)-\left(\bar{M}_{y} \cos \varphi+\bar{M}_{x} \sin \varphi\right)\right\} \delta v_{s}^{\prime}\right]_{z_{1}}^{z_{2}}+\int_{z_{1}}^{z_{2}}\left[M_{\omega^{\prime \prime}}{ }^{\prime \prime} M_{y}\left(u_{s}^{\prime \prime} \cos \varphi+v_{s}^{\prime \prime} \sin \varphi\right)\right.$ $+M_{x}\left(v_{s}^{\prime \prime} \cos \varphi-u_{s}^{\prime \prime} \sin \varphi\right)+\left[N\left\{\left(y_{s} u_{s}{ }^{\prime}-x_{s} v_{s}{ }^{\prime}\right) \cos \varphi+\left(x_{s} u_{s}{ }^{\prime}+y_{s} v_{s}{ }^{\prime}\right) \sin \varphi\right\}+K \varphi^{\prime}\right]^{\prime}$ $-N\left\{\left(x_{s} u_{s}{ }^{\prime}+y_{s} v^{\prime}{ }^{\prime}{ }^{\prime}\right) \cos \varphi-\left(y_{s} u_{s}{ }^{\prime}-x_{x} v_{s}{ }^{\prime}\right) \sin \varphi\right\} \varphi^{\prime}+T_{s}{ }^{\prime}+m_{t} \cos \varphi+m_{t n} \sin \varphi+m_{y}\left(u_{s}{ }^{\prime} \cos \varphi\right.$ $\left.\left.-v_{s}^{\prime} \sin \varphi\right)-m_{x}\left(v_{s}^{\prime} \cos \varphi-u_{s}^{\prime} \sin \varphi\right)+m_{\omega^{\prime}}{ }^{\prime}\right] \delta \varphi d z+\left[\left[-M_{\omega^{\prime}}-T_{s}-N\left\{\left(u_{s}{ }^{\prime} y_{s}-v^{\prime}{ }^{\prime} x_{s}\right) \cos \varphi\right.\right.\right.$ $\left.+\left(u_{s}{ }^{\prime} x_{s}+v_{s}{ }^{\prime} y_{s}\right) \sin \varphi\right\}-K \varphi^{\prime}-m_{\omega}+\bar{M}_{x}\left(u_{s}{ }^{\prime} \sin \varphi-v_{s}{ }^{\prime} \cos \varphi\right)+\bar{M}_{y}\left(u_{s}{ }^{\prime} \cos \varphi+v_{s}{ }^{\prime} \sin \varphi\right)$ $\left.\left.+\bar{T} \cos \varphi-\bar{T}_{n} \sin \varphi\right] \delta \varphi\right]_{z_{1}}^{z_{2}}+\left[\left[M_{\omega}-\bar{M}_{\omega}\right] \delta \varphi^{\prime}\right]_{z_{1}}^{z_{2}}=0$

ここに,

$$
\begin{aligned}
& N=\int_{A} \sigma_{z} d A, M_{x}=\int_{A} \sigma_{z} x d A, M_{y}=\int_{A} \sigma_{z} y d A \\
& M_{\omega}=\int_{A} \sigma_{z} \omega d A, \\
& K=\int_{A} \sigma_{z}\left\{\left(x-x_{s}\right)^{2}+\left(y-y_{s}\right)^{2}\right\} d A \cdots(3.3 \mathrm{~d}, \mathrm{e}) \\
& T_{s}=\int_{A} \tau_{s z} \theta d A, \quad V_{x}=\int_{A}\left(\tau_{s z} l-\tau_{n z} m\right) d A, \\
& V_{y}=\int_{A}\left(\tau_{s z} m+\tau_{n z} l\right) d A \\
& T=\int_{A}\left(\tau_{s z} \rho_{s}+\tau_{n z} \rho_{n}\right) d A, \\
& T_{n}=\int_{A}\left(\tau_{s z} \rho_{n}-\tau_{n z} \rho_{s}\right) d A \\
& p_{x}=\int_{A} p_{x d} d A, p_{y}=\int_{A} p_{y d} d A, p_{z}=\int_{A} p_{z d} d A \\
& m_{x}=\int_{A} p_{z d} x d A, m_{y}=\int_{A} p_{z d} y d A, \\
& m_{\omega}=\int_{A} p_{z d} \omega d A \\
& m_{t}=\int_{A}\left\{p_{y d}\left(x-x_{s}\right)-p_{x d}\left(y-y_{s}\right)\right\} d A
\end{aligned}
$$

$$
m_{t n}=-\int_{A}\left\{p_{x d}\left(x-x_{s}\right)+p_{y d}\left(y-y_{s}\right)\right\} d A
$$

上付の棒は両端断面での表面力に起因する端部外力を表 わす。任意の仮想変位に対して式 (3.2) が成立するため の必要十分条件として,つり合い方程式と変位および力 学的境界条件を得る。すなわち, $z_{1}<z<z_{2}$ において 次のつり合いの微分方程式を得る。

$$
\begin{aligned}
& N^{\prime}+p_{z}=0 \\
& \left(M_{x} \cos \varphi-M_{y} \sin \varphi\right)^{\prime \prime} \\
& +\left[N\left\{u_{s}{ }^{\prime}+\left(y \cos \varphi+x_{s} \sin \varphi\right) \varphi^{\prime}\right\}\right]^{\prime}+p_{x} \\
& +\left(m_{x} \cos \varphi-m_{y} \sin \varphi\right)^{\prime}=0 \\
& \left(M_{y} \cos \varphi+M_{x} \sin \varphi\right)^{\prime \prime} \\
& +\left[N\left\{v_{s}^{\prime}-\left(x_{s} \cos \varphi-y_{s} \sin \varphi\right) \varphi^{\prime}\right\}\right]^{\prime}+p_{y}
\end{aligned}
$$

$$
\begin{aligned}
& +\left(m_{y} \cos \varphi+m_{x} \sin \varphi\right)^{\prime}=0 . \\
& M_{\omega}{ }^{\prime \prime}-M_{y}\left(u_{s}^{\prime \prime} \cos \varphi+v_{s}^{\prime \prime} \sin \varphi\right)+M_{x}\left(v_{s}^{\prime \prime} \cos \varphi\right. \\
& \left.-u_{s}^{\prime \prime} \sin \varphi\right)+\left[N \left\{\left(y_{s} u_{s}{ }^{\prime}-x_{s} v_{s}{ }^{\prime}\right) \cos \varphi\right.\right. \\
& \left.\left.+\left(x_{s} u_{s}{ }^{\prime}+y_{s} v_{s}{ }^{\prime}\right) \sin \varphi\right\}+K \varphi^{\prime}\right]^{\prime}-N\left\{\left(x_{s} u_{s}{ }^{\prime}\right.\right. \\
& \left.\left.+y_{s} v_{s}{ }^{\prime}\right) \cos \varphi-\left(y_{s} u_{s}{ }^{\prime}-x_{s} v_{s}{ }^{\prime}\right) \sin \varphi\right\} \varphi^{\prime} \\
& +T_{s}{ }^{\prime}+m_{t} \cos \varphi+m_{t n} \sin \varphi+m_{y}\left(u_{s}{ }^{\prime} \cos \varphi\right. \\
& \left.+v_{s}{ }^{\prime} \sin \varphi\right)-m_{x}\left(v_{s}{ }^{\prime} \cos \varphi-u_{s}{ }^{\prime} \sin \varphi\right) \\
& +m_{\omega}{ }^{\prime}=0 \text {. }
\end{aligned}
$$

また, 端部 $z=z_{1}, z_{2}$ における条件から, 両端での境界 条件が次のように求まる。

$$
\begin{aligned}
& w_{c}=C_{1} \text { または } \bar{N}=N \\
& u_{s}=C_{2} \text { または } \\
& \bar{V}_{x}=\left(M_{x} \cos \varphi-M_{y} \sin \varphi\right)^{\prime} \\
& +N\left\{u_{s}{ }^{\prime}+\left(y_{s} \cos \varphi+x_{s} \sin \varphi\right) \varphi^{\prime}\right\} \\
& +\left(m_{x} \cos \varphi-m_{y} \sin \varphi\right)
\end{aligned}
$$

$u_{s}^{\prime}=C_{3}$ または

$\bar{M}_{x} \cos \varphi-\bar{M}_{y} \sin \varphi=M_{x} \cos \varphi-M_{y} \sin \varphi$

$$
\begin{aligned}
v_{s}= & C_{4} \text { または } \\
\bar{V}_{y}= & \left(M_{y} \cos \varphi+M_{x} \sin \varphi\right)^{\prime} \\
& +N\left\{v_{s}^{\prime}-\left(x_{s} \cos \varphi-y_{s} \sin \varphi\right) \varphi^{\prime}\right\} \\
& +\left(m_{y} \cos \varphi+m_{x} \sin \varphi\right) \cdots \cdots \cdots \cdots . . . .
\end{aligned}
$$

$v_{s}{ }^{\prime}=C_{5}$ または

$\bar{M}_{y} \cos \varphi+\bar{M}_{x} \sin \varphi=M_{y} \cos \varphi+M_{x} \sin \varphi$

$$
\varphi=C_{6} \text { または }
$$

$\bar{T} \cos \varphi-\bar{T}_{n} \sin \varphi+\bar{M}_{y}\left(u_{s}^{\prime} \cos \varphi+v_{s}{ }^{\prime} \sin \varphi\right)$ $-\bar{M}_{x}\left(v_{s}^{\prime} \cos \varphi-u_{s}{ }^{\prime} \sin \varphi\right)$

$$
\begin{aligned}
= & T_{s}+M_{\omega}^{\prime}+N\left\{\left(y_{s} u_{s}^{\prime}-x_{s} v_{s}^{\prime}\right) \cos \varphi\right. \\
& \left.+\left(x_{s} u_{s}^{\prime}+y_{s} v_{s}^{\prime}\right) \sin \varphi\right\}+K \varphi^{\prime}+m_{\omega}
\end{aligned}
$$

$\varphi^{\prime}=C_{7}$ または $\bar{M}_{\omega}=M_{\omega}$

ここに, $C_{1} \sim C_{7}$ は定数である。

\section{4. 断面カと变位の関保}

一次元の棒理論に表われる直応力と直ひずみに関する 
忘力ーひずみ関係の仮定から

$$
\sigma_{z}=E \epsilon_{z}
$$

ここに $E$ は弾性係数である。せん断応力とせん断ひず みの間には次の関係がある。

$$
\tau_{s z}=2 G \gamma_{s z}
$$

式 (3.3) に式 (2.26) および (4.1) を代大する上, 断面 力-変位の関係が得られる。一般に $x y$ 座標の原点 $C$, $s$ 座標の原点 0 および変位 $u_{s}, v_{s}$ が定義されている点 $S$ は任意に選びうる。しかしながら，これらの点を次の 条件を満足するように選ぶと, 断面力-変位の関係を簡 単化することができる。

$$
\begin{gathered}
\int_{A} x d A=0, \int_{A} y d A=0, \int_{A} x y d A=0 \\
\ldots \ldots \ldots \ldots \ldots \cdots \cdots \cdots \cdot \ldots \cdot(4.2 \\
\int_{A} \omega d A=0, \int_{A} \omega x d A=0, \int_{A} \omega y d A=0
\end{gathered}
$$

式 $(4.2 \mathrm{a} \sim \mathrm{c})$ から $C$ の位置と座標の方向が決まり，こ のとき $x y$ 座標は断面主軸と一致する。式 (2.25) を $(4.2 \mathrm{~d})$ に代入すると任意に選んだ点 0 ，および 0 と $C$ の任意の結び方について

$$
\Omega_{c} *=\int_{A} \Omega * d A / A
$$

を得る。ここに $A$ は断面積である。式 $(4.2 \mathrm{e}, \mathrm{f})$ に よって, 点 $S$ の $x, y$ 座標が定まり, せん断中心と一 般によばれる点と一致する。

式 (4.2) の関係を用いると, 断面力一変位の関係は次 のようになる。

$$
\begin{aligned}
& N=E A \tilde{\mathfrak{w}}_{c}^{\prime}+\frac{1}{2} E I_{p 0} \varphi^{\prime 2} \\
& M_{y}=-E I_{y y} \tilde{v}_{s}^{\prime \prime}+\frac{1}{2} E I_{p y} \varphi^{\prime 2} \\
& M_{x}=-E I_{x x} \tilde{u}_{s}^{\prime \prime}+\frac{1}{2} E I_{p x} \varphi^{\prime 2} \\
& M_{\omega}=-E I_{\omega \omega} \varphi^{\prime \prime}+\frac{1}{2} E I_{p \omega} \varphi^{\prime 2} \\
& K=E I_{p 0} \tilde{w}_{c}{ }^{\prime}-E I_{p x} \tilde{u}_{s}{ }^{\prime \prime}-E I_{p y} \tilde{v}_{s}^{\prime \prime}-E I_{p \omega} \varphi^{\prime \prime} \\
& +\frac{1}{2} E I_{p p} \varphi^{\prime 2}
\end{aligned}
$$

$$
T_{s}=G J_{s} \varphi^{\prime}
$$

ここに,

$$
\begin{aligned}
& \tilde{w}_{c}^{\prime}=\tau_{c}^{\prime}{ }^{\prime}+\frac{1}{2}\left(u_{s}^{\prime 2}+v_{s}^{\prime 2}\right)+\left\{\left(y_{s} u_{s}^{\prime}-x_{s} v_{s}^{\prime}\right)\right. \\
& \left.\cdot \cos \varphi+\left(x_{s} u_{s}{ }^{\prime}+y_{s} v_{s}{ }^{\prime}\right) \sin \varphi\right\} \varphi^{\prime} \cdots(4.5 \mathrm{a}) \\
& \tilde{u}_{s}^{\prime \prime}=u_{s}^{\prime \prime} \cos \varphi+v_{s}^{\prime \prime} \sin \varphi \\
& \tilde{v}_{s}^{\prime \prime}=v_{s}^{\prime \prime} \cos \varphi-u_{s}^{\prime \prime} \sin \varphi \\
& A=\int_{A} d A, I_{x x}=\int_{A} x^{2} d A, I_{y y}=\int_{A} y^{2} d A \\
& I_{\omega \omega}=\int_{A} \omega^{2} d A, J_{s}=\int_{A} \theta^{2} d A \\
& I_{p 0}=\int_{A} \rho_{s n^{2}} d A, I_{p x}=\int_{A} x \rho_{s n}^{2} d A, \\
& I_{p y}=\int_{A} y \rho_{s n^{2}} d A \\
& I_{p \omega}=\int_{A} \omega \rho_{s n^{2}} d A, I_{p p}=\int_{A}\left(\rho_{s n}\right)^{2} d A
\end{aligned}
$$

ただし，

$$
\rho_{s n}{ }^{2}=\rho_{s}^{2}+\rho_{n}^{2}=\left(x-x_{s}\right)^{2}+\left(y-y_{s}\right)^{2}
$$

式 $(4.4 \mathrm{a} \sim \mathrm{d})$ を用いると式 $(4.4 \mathrm{e})$ は次のように表わ せる。

$$
K=i_{p 0}^{2} N+i_{p x} M_{x}+i_{p y} M_{y}+k_{p \omega} M_{\omega}+\tilde{K}
$$

$こ こ に$

$$
\begin{aligned}
& i_{p 0}=\sqrt{\frac{I_{p 0}}{A}}, i_{p x}=\frac{I_{p x}}{I_{x x}}, i_{p y}=\frac{I_{p y}}{I_{y y}}, k_{p \omega}=\frac{I_{p \omega}}{I_{\omega \omega}} \\
& \ldots \ldots \ldots \ldots \ldots \ldots \ldots(4.9 \mathrm{a} \sim \mathrm{d}) \\
& \tilde{K}=\frac{1}{2} E \tilde{I}_{p p}\left(\varphi^{\prime}\right)^{2} \ldots \ldots \ldots \ldots \ldots \ldots \ldots \ldots \ldots(4.10) \\
& \tilde{I}_{p p}=I_{p p}-i_{p 0}{ }^{2} I_{p 0}-i_{p x} I_{p x}-i_{p y} I_{p y}-k_{p \omega} I_{p \omega}
\end{aligned}
$$

\section{5. つり合いの微分方程式の变位表示}

式 (3.4) に式 (4.4) を代入すると, 変位表示のつり 合いの微分方程式が次のように求められる。

$$
\left(E A \tilde{w}_{c}^{\prime}+\frac{1}{2} E I_{p 0} \varphi^{\prime 2}\right)^{\prime}+p_{z}=0
$$

$$
-\left\{E\left(I_{x x} \tilde{u}_{s}^{\prime \prime}-\frac{1}{2} I_{p x} \varphi^{\prime 2}\right) \cos \varphi-E\left(I_{y y} \tilde{v}_{s}^{\prime \prime}-\frac{1}{2} I_{p y} \varphi^{\prime 2}\right) \sin \varphi\right\}^{\prime \prime}+\left[E\left(A \tau \tilde{\vartheta}_{c}^{\prime}+\frac{1}{2} I_{p 0} \varphi^{\prime 2}\right)\right.
$$$$
\text { - } \left.\left\{u_{s}^{\prime}+\left(y_{s} \cos \varphi+x_{s} \sin \varphi\right) \varphi^{\prime}\right\}\right]^{\prime}+p_{x}+\left(m_{x} \cos \varphi-m_{y} \sin \varphi\right)^{\prime}=0
$$

$$
-\left\{E\left(I_{y y} \tilde{v}_{s}^{\prime \prime}-\frac{1}{2} I_{p y} \varphi^{\prime 2}\right) \cos \varphi+\left(I_{x x} \tilde{u}_{s}^{\prime \prime}-\frac{1}{2} I_{p x} \varphi^{\prime 2}\right) \sin \varphi\right\}^{\prime \prime}+\left[E\left(A \tilde{w}_{c}^{\prime}+\frac{1}{2} I_{p 0} \varphi^{\prime 2}\right)\right.
$$$$
\text { - } \left.\left\{v_{s}{ }^{\prime}-\left(x_{s} \cos \varphi-y_{s} \sin \varphi\right) \varphi^{\prime}\right\}\right]^{\prime}+p_{y}+\left(m_{y} \cos \varphi+m_{x} \sin \varphi\right)^{\prime}=0
$$

$$
\begin{aligned}
& -E\left(I_{\omega \omega} \varphi^{\prime \prime}-\frac{1}{2} I_{p \omega} \varphi^{\prime 2}\right)^{\prime \prime}-E\left(I_{x x} \tilde{u}_{s}^{\prime \prime}-\frac{1}{2} I_{p x} \varphi^{\prime 2}\right) \tilde{v}_{s}^{\prime \prime}+E\left(I_{y y} \tilde{v}_{s}^{\prime \prime}-\frac{1}{2} I_{p y} \varphi^{\prime 2}\right) \tilde{u}_{s}^{\prime \prime}+\left[E\left(A \tilde{v}_{c}^{\prime}+\frac{1}{2} I_{p 0} \varphi^{\prime 2}\right)\right. \\
& \left.\cdot\left\{\left(y_{s} u_{s}^{\prime}-x_{s} v_{s}^{\prime}\right) \cos \varphi+\left(x_{s} u_{s}^{\prime}+y_{s} v_{s}^{\prime}\right) \sin \varphi\right\}+\left(I_{p 0} \tilde{v}_{c}^{\prime}-I_{p x} \tilde{u}_{s}^{\prime \prime}-I_{p y} \tilde{v}_{s}^{\prime \prime}-I_{p \omega} \varphi^{\prime \prime}+\frac{1}{2} I_{p p} \varphi^{\prime 2}\right) \varphi^{\prime}\right]^{\prime}
\end{aligned}
$$


$-E\left(A v \tilde{v}_{c}{ }^{\prime}+\frac{1}{2} I_{p_{0}} \varphi^{\prime 2}\right)\left\{\left(x_{s} u_{s}^{\prime}+y_{s} v_{s}^{\prime}\right) \cos \varphi-\left(y_{s} u_{s}^{\prime}-x_{s} v_{s}^{\prime}\right) \sin \varphi\right\} \varphi^{\prime}+\left(G J \varphi^{\prime}\right)^{\prime}+m_{t} \cos \varphi$

$-m_{t n} \sin \varphi+m_{y}\left(u_{s}^{\prime} \cos \varphi-v_{s}^{\prime} \sin \varphi\right)-m_{x}\left(v_{s}{ }^{\prime} \cos \varphi-u_{s}{ }^{\prime} \sin \varphi\right)+m_{t,}^{\prime}=0$

\section{6. 断面内の応力分布}

式 (4.4 a d)，(4.10) および (4.4f) を式 (2.26) に 代入し, 式 (4.1) の関係を用いると, 仮定した变位場に 対応した断面内の応力分布を表わす式として次のものを 得る。

$$
\begin{aligned}
& \sigma_{z}=\frac{1}{A}\left(N-\frac{I_{p 0}}{\tilde{I}_{p p}} \tilde{K}\right)+\frac{x}{I_{x x}}\left(M_{x}-\frac{I_{p x}}{\tilde{I}_{p p}} \tilde{K}\right) \\
& +\frac{y}{I_{y y}}\left(M_{y}-\frac{I_{p y}}{\tilde{I}_{p p}} \tilde{K}\right)+\frac{\omega}{I_{\omega \omega}}\left(M_{\omega}-\frac{I_{p \omega}}{\tilde{I}_{p p}} \tilde{K}\right) \\
& +\rho_{s n^{2}} \frac{1}{\tilde{I}_{p p}} \tilde{K} \\
& \tau_{s z}=\frac{T_{s}}{J_{s}} \Theta \\
& \tau_{n z}=0
\end{aligned}
$$

しかしながら，オイラー・ベルヌイの仮定から，式 (2.15) 右辺第 2 項のせん断ひずみを無視したため, 式 (6.1) で表わされる応力場は, 一般に微小要素について のつり合いを満足しない。微小要素についてもつり合い 状態にある応力場を求めるために, 一次元の棒理論では オイラー・ベルヌイの仮定に基づいて得られた直応力と つり合うようにせん断応力を修正することが一般に行わ れている。ひずみ椡小であるとすると, 薄肉であるこ とにより微小要素 $t d s d z$ は変形後もほぼ直方体である と見なせるから，変位後の $z$ 方向の力のつり合い式は 次のように表わせる。

$$
\begin{array}{r}
\frac{\partial}{\partial s}\left[\int_{-t / 2}^{t / 2} \tau_{s z} d n\right]+\frac{\partial}{\partial z}\left[\int_{-t / 2}^{t / 2} \sigma_{z} d n\right] \\
+\int_{-t / 2}^{t / 2} \tilde{p}_{z d} d n=0 \ldots \ldots \ldots \ldots \ldots \ldots \ldots \ldots \ldots \ldots \ldots \ldots \ldots
\end{array}
$$

ここに

$$
\tilde{p}_{z d}=p_{x d} \frac{\partial u}{\partial z}+p_{y d} \frac{\partial v}{\partial z}+p_{z d}\left(1+\frac{\partial w}{\partial z}\right)
$$

$\tau_{s z}$ は薄肉の前提から $n$ の一次関数であることに注目す ると，式 (6.1 a) を式 (6.2) に代入して,

$$
\begin{aligned}
& \frac{\partial}{\partial s}\left(\tau_{s z}{ }^{*} t\right)+\frac{\partial}{\partial z}\left[t \left\{\frac{1}{A}\left(N-\frac{I_{p p}}{\tilde{I}_{p p}} \tilde{K}\right)\right.\right. \\
& +\frac{x^{*}}{I_{x x}}\left(M_{x}-\frac{I_{p x}}{\tilde{I}_{p p}} \tilde{K}\right)+\frac{y^{*}}{I_{y y}}\left(M_{y}-\frac{I_{p y}}{\tilde{I}_{p p}} \tilde{K}\right) \\
& \left.\left.+\frac{\omega^{*}}{I_{\omega \omega}}\left(M_{\omega}-\frac{I_{p \omega}}{\tilde{I}_{p p}} \tilde{K}\right)\right\}+\left(\rho_{s n}{ }^{* 2} t+\frac{t^{3}}{12}\right) \frac{\tilde{K}}{\tilde{I}_{p p}}\right] \\
& +\int_{-t / 2}^{t / 2} \tilde{p}_{z d} d n=0
\end{aligned}
$$

を得る。式 (6.4)を $s$ について積分すると，

$$
\tau_{s z} *=\frac{q_{1}}{t} \div \tau_{0} *
$$

となる。ここに， $q_{1}=\left(\tau_{s z}{ }^{*} t\right)_{s=s_{1}}$ は積分定数であり，

$$
\begin{aligned}
& \tau_{\sigma}^{*}=-\frac{1}{t}\left[\frac{A_{s}}{A}\left(N^{\prime}-\frac{I_{p 0}}{\tilde{I}_{p p}} \tilde{K}^{\prime}\right)+\frac{Q_{x}}{I_{x x}}\left(M_{x}^{\prime}-\frac{I_{p x}}{\tilde{I}_{p p}} \tilde{K}^{\prime}\right)\right. \\
& +\frac{Q_{y}}{I_{y y}}\left(M_{y^{\prime}}-\frac{I_{p y}}{\tilde{I}_{p p}} \tilde{K}^{\prime}\right)+\frac{Q_{\omega}}{I_{\omega \omega}}\left(M_{\omega}^{\prime}-\frac{I_{p \omega}}{\tilde{I}_{p p}} \tilde{K}^{\prime}\right) \\
& \left.+\frac{Q_{p}}{\tilde{I}_{p p}} \tilde{K}\right]-\frac{q_{p}}{t} \\
& A_{s}=\int_{s_{1}}^{s} t d s, Q_{x}=\int_{s_{1}}^{s} x^{*} t d s, Q_{y}=\int_{s_{1}}^{s} y^{*} t d s \\
& \cdot(6.7 \mathrm{a} \sim \mathrm{c}) \\
& Q_{\omega}=\int_{s_{1}}^{s} \omega^{*} t d s, \quad Q_{p}=\int_{s_{1}}^{s}\left(\rho_{s n}{ }^{* 2} t+\frac{1}{12} t^{3}\right) d s \\
& q_{p}=\int_{s_{1}}^{s} \int_{-t / 2}^{t / 2} \tilde{p}_{z d} d n d s
\end{aligned}
$$

である。開区間では自由縁でのせん断流， $q=\tau_{s z}{ }^{*} t$, に 関する境界条件から $q_{1}$ を決めることができ，自由縁に $s_{1}$ をとると $q_{1}=0$ となる。閉区間では $q_{1}$ は一般に不 静定せん断流といわれるものであり，閉区間での変位 w の連続条件, 式 (2.18) 加決まる。式 (6.5) をせ ん断弹性係数 $G$ でわってせん断ひずみで表わしたもの を，式 $(2.10 \mathrm{a})$ に代入すると

$$
\begin{aligned}
\frac{\partial w^{*}}{\partial s}= & \frac{1}{G}\left(\frac{q_{1}}{t}+\tau_{0}{ }^{*}\right)-l\left(u_{s}{ }^{\prime} \cos \varphi+v_{s}{ }^{\prime} \sin \varphi\right) \\
& -m\left(v_{s}{ }^{\prime} \cos \varphi-u_{s}{ }^{\prime} \sin \varphi\right)-\rho_{s}^{*} \varphi^{\prime}
\end{aligned}
$$

を得る。この式を式 (2.18) に代入すると， $q_{1}$ は次の ように求まる。

$$
q_{1}=G \cdot \frac{\oint \rho_{s}^{*} d s}{\oint \frac{1}{t} d s} \varphi^{\prime}-\frac{\oint \tau_{\sigma} d s}{\oint \frac{1}{t} d s}
$$

上式の右辺第一項は Bredt のせん断流といわれるもの であり, 式 (2.19) で示されるものと同じである。第二 項は付加せん断流（二次せん断流）に対する不静定せん 断流である。

式 (2.12) を $s$ で微分し，それに式 (6.8) を代入す る。この $\partial w / \partial s$ と式 (2.4) と (2.6a) の $u, v, \xi$ を 用いて式 $(2.10 \mathrm{a})$ から $r_{s z}$ が計算でき，これと式 $(4.1 \mathrm{~b})$ から $\tau_{s z}$ が求まる。式 $(2.27)$ と $(4.4 \mathrm{f})$ を用 いて $\tau_{s z}$ を表わすと，開断面または開区間に対し，

$$
\tau_{s z}=\frac{T_{s}}{J_{s}} \theta+\tau_{\sigma}
$$

閉断面または閉区間に対し

$$
\tau_{s z}=\frac{T_{s}}{J_{s}} \theta_{-i-\tau_{\sigma}}-\frac{\oint \tau_{\sigma} d s}{\oint \frac{1}{t} d s} \cdot \frac{1}{t}
$$


となる注 4)。ただし，開断面または開区間に対しては， 式（6.7）の積分の始点を自由縁にとるものとする。

\section{7. 座屈}

有限変位の問題として，最も古くから 取扱われてき た，いわゆる分岐形の安定問題（座屈）に対寸る基本式 を求める。安定限界は一定の荷重条件, 境界条件のもと で,ごく微少な差を有する 2 つの独立な解が存在する条 件から求まる。今，独立な 2 つの解を上付きの $(0) ，(1)$ で表わし，その差を」を付して表わすと，その条件は 一般に次のように表わせる。

$$
\begin{aligned}
& \Delta u=u^{(1)}-u^{(0)} \ll u^{(0)} \ldots \\
& \Delta v=v^{(1)}-v^{(0)} \ll v^{(0)} \ldots \\
& \Delta w=w^{(1)}-w^{(0)} \ll w^{(0)}
\end{aligned}
$$

ひずみ，応力の成分も変位に依存する量であるから，当 然同様の関係が成り立つ。

（0）系，(1) 系ともにつり合い状態を満足しているの で, どちらの系に対しても式 (3.1) の仮想仕事の原理が 成り立つ。荷重条件は両系において，同一であるので， これを明らかにするために両系に対し荷重項には（0)を 付して表わすと，式 (3.1) は次のように表わせる。

$$
\begin{aligned}
& \int_{z_{1}}^{z_{2}} \int_{A}\left[\sigma_{z}^{(1)} \delta \epsilon_{z}^{(1)}+\tau_{s z^{(1)}} \delta r_{s z^{(1)}}\right] d A d z \\
& =\int_{z_{1}}^{z_{2}} \int_{A}\left[p_{x d^{(0)} \delta u^{(1)}+p_{y d}(0) \hat{o} \tau^{(1)}}\right. \\
& \left.+p_{z d^{(0)}} \delta w^{(1)}\right] d A d z \\
& +\left[\int_{A}\left(\bar{\sigma}_{z}{ }^{(0)} \delta r w^{(1)}+\bar{\tau}_{s z^{(0)}} \tilde{\xi}^{(1)}+\bar{\tau}_{\eta z^{(0)}} \delta \eta^{(1)}\right) d A\right]_{z_{1}}^{z_{2}} \\
& \int_{z_{1}}^{z_{2}} \int_{A}\left[\sigma_{z}^{(0)} \delta \epsilon_{z}{ }^{(0)}+\tau_{s z^{(0)}} \delta r_{s z^{(0)}}\right] d A d z \\
& =\int_{z_{1}}^{z_{2}} \int_{A}\left[p_{x d^{(0)}} \delta u^{(0)}+p_{y d^{(0)}} \delta r^{(0)}\right. \\
& \left.+p_{z d^{(0)}} \delta w^{(0)}\right] d A d z \\
& +\left[\int_{A}\left[\bar{\sigma}_{x}^{(0)} \delta w^{(0)}+\bar{\tau}_{s z^{(0)}} \dot{\xi} \xi^{(0)}+\bar{\tau}_{y z^{(0)}} \delta \eta^{(0)}\right] d A\right]_{z_{1}}^{z_{2}}
\end{aligned}
$$

式 (7.2) と (7.3) から得られるつり合い式の差をと り, 式 (7.1) の関係から $\Delta$ を付した微小な項の 2 次項 を省略すると，式 (3.4a〜d) のつり合い式に対応する，

注 4) このせん断応力と式 $(6.1 \mathrm{a})$ の $\sigma_{\boldsymbol{z}}$ とは, 微小要索 $t d s d z$ についてのつり合いを満足する。仮定した変位場 からは $\tau_{n z}=0$ となるが, 微小要素として板厚方向にも 分割した $d n d s d z$ を考えると，この $\tau_{s z}, \sigma_{z}$ のみでは $z$ 方向の力のつり合い条件を满たさず，一般には $\tau_{n z}$ の 存在も必要となる。式 (6.1 a), (6.10)の $\sigma_{z}, \tau_{s z}$ が作 用するものとすると, $d n d s d z$ についての力のつり合い を满たすように $\tau_{n z}$ を補正することができる。しかし， 薄肉の前提加ら $\tau_{n z}$ の值そのものは小さいと考えられ るので,ここでは計算を省略する。
安定限界状態に対するつり合い式として次式を得る。た だし，微小差を表わす記号 $\Delta$ は表式を簡単にするため 省略した。以後この章では，これ以前の章で一般的な変 位や応力を表わしていた記号を, 安定限界での変位や応 力の変化分を表わすものとして用いる。

$$
N^{\prime}=0
$$

$$
\begin{aligned}
& \left\{\cos \varphi^{(0)}\left(M_{x}-M_{y}{ }^{(0)} \varphi\right)-\sin \varphi^{(0)}\left(M_{y}+M_{x}{ }^{(0)} \varphi\right)\right\}^{\prime \prime} \\
& \quad+\left[N ^ { ( 0 ) } \left\{u_{s}{ }^{\prime}+\left(x_{s} \cos \varphi^{(0)}-y_{s} \sin \varphi^{(0)}\right) \varphi^{(0)^{\prime}} \varphi\right.\right. \\
& \left.\left.\quad+\left(y_{s} \cos ^{(0)}+x_{s} \sin \varphi^{(0)}\right) \varphi^{\prime}\right\}\right]^{\prime} \\
& \quad+\left\{u_{s}{ }^{(0) \prime}+\left(y_{s} \cos \varphi^{(0)}+x_{s} \sin \varphi^{(0)}\right) \varphi^{(0)}\right\}^{\prime} N \\
& \quad-\left\{\left(m_{x}{ }^{(0)} \sin \varphi^{(0)}+m_{y}{ }^{(0)} \cos \varphi^{(0)}\right) \varphi\right\}^{\prime}=0
\end{aligned}
$$

$\left\{\cos \varphi^{(0)}\left(M_{y}+M_{x}^{(0)} \varphi\right)+\sin \varphi^{(0)}\left(M_{x}+M_{y}{ }^{(0)} \varphi\right)\right\}^{\prime \prime}$

$$
\begin{aligned}
& +\left[N ^ { ( 0 ) } \left\{v_{s}{ }^{\prime}+\left(y_{s} \cos \varphi^{(0)}+x_{s} \sin \varphi^{(0)}\right) \varphi^{(0) \prime} \varphi\right.\right. \\
& \left.\left.-\left(x_{s} \cos \varphi^{(0)}-y_{s} \sin \varphi^{(0)}\right) \varphi^{\prime}\right\}\right]^{\prime} \\
& +\left\{v_{s}{ }^{(0) \prime}-\left(x_{s} \cos \varphi^{(0)}-y_{s} \sin \varphi^{(0)}\right) \varphi^{(0) \prime}\right\}^{\prime} N \\
& +\left\{\left(m_{x}{ }^{(0)} \cos \varphi^{(0)}-m_{y}{ }^{(0)} \sin \varphi^{(0)}\right) \varphi\right\}^{\prime}=0
\end{aligned}
$$

$$
\begin{aligned}
& M_{\omega}{ }^{\prime \prime}+T_{s}{ }^{\prime}+\left(v_{s}^{(0) \prime \prime} \cos \varphi^{(0)}-u_{s}^{(0) \prime \prime} \sin \varphi^{(0)}\right) M_{x} \\
& \left.-\left(u_{s}{ }^{(0)}\right) \cos \varphi^{(0)}+v_{s}{ }^{(0)} \prime \sin \varphi^{(0)}\right) M_{y} \\
& -\left(M_{y}{ }^{(0)} \cos \varphi^{(0)}+M_{x}{ }^{(0)} \sin \varphi^{(0)}\right) u_{s}{ }^{\prime \prime} \\
& +\left(M_{x}{ }^{(0)} \cos \varphi^{(0)}-M_{y}{ }^{(0)} \sin \varphi^{(0)}\right) v_{s}^{\prime \prime} \\
& -\left\{\cos \varphi^{(0)}\left(M_{x}{ }^{(0)} u_{s}{ }^{(0) \prime \prime}+M_{y}{ }^{(0)} v_{s}{ }^{(0) \prime \prime}\right)\right. \\
& \left.\left.\left.\left.+\sin \varphi^{(0)}\left(M_{x}{ }^{(0)} v_{s}{ }^{(0)}\right)-M_{y}{ }^{(0)} u_{s}{ }^{(0)}\right)\right\}\right)\right\} \\
& +\left[N ^ { ( 0 ) } \left[\left(y_{s} \cos \varphi^{(0)}+x_{s} \sin \varphi^{(0)}\right) u_{s}^{\prime}\right.\right. \\
& -\left(x_{s} \cos \varphi^{(0)}-y_{s} \sin \varphi^{(0)}\right) v_{s}{ }^{\prime} \\
& +\left\{\cos \varphi^{(0)}\left(x_{s} u_{s}{ }^{(0) \prime}+y_{s} v_{s}{ }^{(0) \prime}\right)\right. \\
& \left.\left.+\sin \varphi^{(0)}\left(x_{s} v_{s}{ }^{(0) \prime}-y_{s} u_{s}^{(0) \prime}\right)\right\} \varphi\right] \\
& \left.+\left(\varphi^{(0) \prime} K+K^{(0)} \varphi^{\prime}\right)\right]^{\prime}+\left\{\operatorname { c o s } \varphi ^ { ( 0 ) } \left(y_{s} u_{s}^{(0) \prime \prime}\right.\right. \\
& \left.\left.-x_{s} v_{s}^{(0) \prime \prime}\right)+\sin \varphi^{(0)}\left(x_{s} u_{s}{ }^{(0) \prime \prime}+y_{s} v_{s}^{(0) \prime \prime}\right)\right\} N \\
& -N^{(0)}\left[\varphi ^ { ( 0 ) } { } ^ { \prime } \left[\left(x_{s} \cos \varphi^{(0)}-y_{s} \sin \varphi^{(0)}\right) u_{s}^{\prime}\right.\right. \\
& +\left(y_{s} \cos \varphi^{(0)}+x_{s} \sin \varphi^{(0)}\right) v_{s}^{\prime} \\
& +\left\{\cos \varphi^{(0)}\left(x_{s} v_{s}^{(0) \prime}-y_{s} u_{s}^{(0) \prime}\right)\right. \\
& \left.\left.-\sin \varphi^{(0)}\left(x_{s} u_{s}^{(0) \prime}+y_{s} v_{s}^{(0) \prime}\right)\right\} \varphi\right] \\
& +\left\{\cos \varphi^{(0)}\left(x_{s} u_{s}^{(0) \prime}+y_{s} v_{s}^{(0) \prime}\right)\right. \\
& \left.+\sin \varphi^{(0)}\left(x_{s} v_{s}{ }^{(0) \prime}-y_{s} u_{s}^{(0) \prime}\right\} \varphi^{\prime}\right] \\
& -\left(m_{t}{ }^{(0)} \sin \varphi^{(0)}-m_{t n^{(0)}} \cos \varphi^{(0)}\right) \varphi \\
& -m_{x}{ }^{(0)}\left\{\sin \varphi^{(0)} u_{s}^{\prime}-\cos \varphi^{(0)} v_{s}{ }^{\prime}\right. \\
& \left.+\left(u_{s}{ }^{(0) \prime} \cos \varphi^{(0)}+v_{s}{ }^{(0) \prime} \sin \varphi^{(0)}\right) \varphi\right\} \\
& +m_{y}{ }^{(0)}\left\{\cos \varphi^{(0)} u_{s}{ }^{\prime}+\sin \varphi^{(0)} v_{s}{ }^{\prime}\right. \\
& \left.+\left(\tau^{{ }^{\prime}}{ }^{\prime(0)} \cos \varphi^{(0)}-u_{s}{ }^{(0)} \sin \varphi^{(0)}\right) \varphi\right\}=0 \cdots(7.4 \mathrm{~d})
\end{aligned}
$$

安定問題に対する部材両端での境界条件は式 (3.5)に 対応し次のように求まる。

$$
\begin{aligned}
& w_{c}=0 \text { または } N=0 \\
& u_{s}=0 \text { または } \\
& \left\{M_{x} \cos \varphi^{(0)}-M_{y} \sin \varphi^{(0)}-\left(M_{y}{ }^{(0)} \cos \varphi^{(0)}\right.\right. \\
& \left.\left.+M_{x}^{(0)} \sin \varphi^{(0)}\right) \varphi\right\}^{\prime}+N^{(0)}\left\{u_{s}{ }^{\prime}-\left(y_{s} \sin \varphi^{(0)}\right.\right.
\end{aligned}
$$




$$
\begin{aligned}
& \left.-x_{s} \cos \varphi^{(0)}\right) \varphi^{(0) \prime} \varphi+\left(y_{s} \cos \varphi^{(0)}\right. \\
& \left.\left.+x_{s} \sin \varphi^{(0)}\right) \varphi^{\prime}\right\}+N\left\{u_{s}{ }^{(0) \prime}+\left(y_{s} \cos \varphi^{(0)}\right.\right. \\
& \left.\left.+x_{s} \sin \varphi^{(0)}\right) \varphi^{(0) \prime}\right\}-\left(m_{y}{ }^{(0)} \cos \varphi^{(0)}+\right. \\
& \left.\quad m_{x}{ }^{(0)} \sin \varphi^{(0)}\right) \varphi=0 \cdots \cdots \cdots \cdots \cdots \cdots \cdots(7.5
\end{aligned}
$$

$$
u_{s}^{\prime}=0 \text { または }
$$

$$
\begin{aligned}
M_{x} & \cos \varphi^{(0)}-M_{y} \sin \varphi^{(0)} \\
& -\left(M_{y}{ }^{(0)} \cos \varphi^{(0)}+M_{x}{ }^{(0)} \sin \varphi^{(0)}\right) \varphi \\
= & -\left(\bar{M}_{y}{ }^{(0)} \cos \varphi^{(0)}+\bar{M}_{x}{ }^{(0)} \sin \varphi^{(0)}\right) \varphi
\end{aligned}
$$

$$
\begin{aligned}
& v_{s}=0 \text { または } \\
& \left\{M_{y} \cos \varphi^{(0)}+M_{x} \sin \varphi^{(0)}+\left(M_{x}{ }^{(0)} \cos \varphi^{(0)}\right.\right. \\
& \left.\left.-M_{y}{ }^{(0)} \sin \varphi^{(0)}\right) \varphi\right\}^{\prime}+\Lambda^{(0)}\left\{v_{s}{ }^{\prime}+\left(y_{s} \cos \varphi^{(0)}\right.\right. \\
& \left.\div x_{s} \sin \varphi^{(0)}\right) \varphi^{(0)} \varphi-\left(x_{s} \cos \varphi^{(0)}\right. \\
& \left.\left.-y_{s} \sin \varphi^{(0)}\right) \varphi^{\prime}\right\}+N\left\{z_{s}{ }^{(0) \prime}-\left(x_{s} \cos \varphi^{(0)}\right.\right. \\
& \left.\left.-y_{s} \sin \varphi^{(0)}\right) \varphi^{(0) \prime}\right\}-\left(m_{x}{ }^{(0)} \cos \varphi^{(0)}\right. \\
& \left.-m_{y}{ }^{(0)} \sin \varphi^{(0)}\right) \varphi=0
\end{aligned}
$$

$r^{\prime}{ }^{\prime}=0$ または

$M_{y} \cos \varphi^{(0)}+M_{x} \sin \varphi^{(0)}$

$$
\begin{aligned}
& +\left(M_{x}{ }^{(0)} \cos \varphi^{(0)}-M_{y}{ }^{(0)} \sin \varphi^{(0)}\right) \varphi \\
= & \left(\bar{M}_{x}{ }^{(0)} \cos \varphi^{(0)}-\bar{M}_{y}{ }^{(0)} \sin \varphi^{(0)}\right) \cdots(7.5 \mathrm{e})
\end{aligned}
$$

$\varphi=0$ または

$$
\begin{aligned}
M_{\omega}{ }^{\prime} & +T_{s}+N^{(0)}\left[\left(y_{s} \cos \varphi^{(0)}+x_{s} \sin \varphi^{(0)}\right) u_{s}{ }^{\prime}\right. \\
& -\left(x_{s} \cos \varphi^{(0)}-y_{s} \sin \varphi^{(0)}\right) v_{s}^{\prime} \\
& +\left\{\left(x_{s} u_{s}{ }^{(0) \prime}+y_{s} \tau^{\prime}{ }^{(0) \prime}\right) \cos \varphi^{(0)}\right. \\
& \left.\left.-\left(y_{s} u_{s}{ }^{(0) \prime}-x_{s} v_{s}^{(0) \prime}\right) \sin \varphi^{(0)}\right\} \varphi\right] \\
& +N\left\{\left(y_{s} u_{s}{ }^{(0) \prime}-x_{s} \tau^{\prime}{ }^{(0) \prime}\right) \cos \varphi^{(0)}\right. \\
& \left.+\left(x_{s} u_{s}{ }^{(0) \prime}+y_{s} v^{\prime}{ }^{(0) \prime}\right) \sin \varphi^{(0)}\right\}+K^{(0)} \varphi^{\prime} \\
& +K \varphi^{(0) \prime} \\
= & -\left(\bar{T}_{n}{ }^{(0)} \cos \varphi^{(0)}+\bar{T}{ }^{(0)} \sin \varphi^{(0)}\right) \varphi \\
& -\bar{M}_{x^{(0)}}\left\{v_{s}{ }^{\prime} \cos \varphi^{(0)}-u_{s}^{\prime} \sin \varphi^{(0)}\right. \\
& \left.-\left(u_{s}{ }^{(0) \prime} \cos \varphi^{(0)}+\tau^{\prime} s^{(0) \prime} \sin \varphi^{(0)}\right) \varphi\right\} \\
& +\bar{M}_{y^{(0)}}\left\{u_{s}{ }^{\prime} \cos \varphi^{(0)}-\tau^{\prime}{ }^{\prime} \sin \varphi^{(0)}\right. \\
& \left.+\left(v_{s}{ }^{(0) \prime} \cos \varphi^{(0)}-u_{s}{ }^{(0) \prime} \sin \varphi^{(0)}\right) \varphi\right\}
\end{aligned}
$$

$\varphi^{\prime}=0$ または $M_{\omega}=0$

安定限界での断面力の変化分と変位の関係は, 式 (4.4)，(4.5) に対応し次に示寸ものとなる。

$$
\begin{aligned}
N= & E A \tilde{w}_{c}^{\prime}+E I_{p 0} \varphi^{(0) \prime} \varphi^{\prime} \\
M_{x}= & -E I_{x x} \tilde{u}_{s}^{\prime \prime}+E I_{p x} \varphi^{(0) \prime} \varphi^{\prime} \\
M_{y}= & -E I_{y y} \tilde{v}_{s}^{\prime \prime}+E I_{p y} \varphi^{(0) \prime} \varphi^{\prime} \\
M_{\omega}= & -E I_{\omega \omega} \varphi^{\prime \prime}+E I_{p \omega} \varphi^{(0) \prime} \varphi^{\prime} \\
K= & E I_{p 0} \tilde{w}_{c}^{\prime}-E I_{p x} \tilde{u}_{s}^{\prime \prime}-E I_{p y} \tilde{v}_{s}^{\prime \prime} \\
& -E I_{p \omega} \varphi^{\prime \prime}+E I_{p p} \varphi^{(0) \prime} \varphi^{\prime} \\
T_{s}= & G J_{s} \varphi^{\prime}
\end{aligned}
$$

$(7.6 \mathrm{a} \sim \mathrm{f})$

$$
\begin{aligned}
\left.\left.\sin \varphi^{(0)}\right)\right\} u_{s}^{\prime} \\
+\left\{v_{s}{ }^{(0) \prime}-\varphi^{(0) \prime}\left(x_{s} \cos \varphi^{(0)}-y_{s} \sin \varphi^{(0)}\right)\right\} v_{s}^{\prime} \\
+\varphi^{(0) \prime}\left\{\left(x_{s} u_{s}{ }^{(0) \prime}+y_{s} v_{s}^{(0) \prime}\right) \cos \varphi^{(0)}\right. \\
\left.-\left(y_{s} u_{s}^{(0) \prime}-x_{s} v_{s}^{(0) \prime}\right) \sin \varphi^{(0)}\right\} \varphi \\
+\left\{\left(y_{s} u_{s}^{(0) \prime}-x_{s} v_{s}^{(0) \prime}\right) \cos \varphi^{(0)}\right. \\
\left.+\left(x_{s} u_{s}^{(0) \prime}+y_{s} v_{s}^{(0) \prime}\right) \sin \varphi^{(0)}\right\} \varphi^{\prime} \cdots(7.7 \mathrm{a}) \\
\tilde{u}_{s}^{\prime \prime}=\cos \varphi^{(0)} u_{s}^{\prime \prime}+\sin \varphi^{(0)} v_{s}^{\prime \prime} \\
\quad+\left(v_{s}^{(0) \prime \prime} \cos \varphi^{(0)}-u_{s}{ }^{(0) \prime \prime} \sin \varphi^{(0)}\right) \varphi
\end{aligned}
$$

$$
\begin{aligned}
\widetilde{v}_{s}{ }^{\prime \prime}= & \cos \varphi^{(0)} v_{s}{ }^{\prime \prime}-\sin \varphi^{(0)} u_{s}{ }^{\prime \prime} \\
& -\left(u_{s}{ }^{(0) \prime \prime} \cos \varphi^{(0)}+v_{s}^{(0) \prime \prime} \sin \varphi^{(0)}\right) \varphi
\end{aligned}
$$

式 (7.6) を式 (7.4) に代入すると, 変位表示した, 安定限界を求めるための支配方程式を得る。以下, 特定 の荷重条件, 境界条件の場合についてこれを求める。た だし,一般に行われている安定問題と異なり, 本報告中 では軸力 $N$ は引張力のとき正となっている。

\section{（1）中心圧縮材の座屈}

荷重としては, 部材の両端に $\bar{N}^{(0)}, \bar{T}_{n}^{(0)}($ 部材端力 は一般に両端で異なった值をとる）と部材軸に沿って分 布する $p_{z}{ }^{(0)}, m_{t n}{ }^{(0)}$ が作用しているとすると, 式 (5.1) より, 式 (3.5) の境界条件を满足する解として

$$
u_{s}^{(0)}=v^{(0)}=\varphi^{(0)}=0
$$

を得る。したがって，式 (4.4), (4.8) から

$$
\begin{aligned}
& M_{x}{ }^{(0)}=M_{y}{ }^{(0)}=M_{\omega}{ }^{(0)}=T_{s}{ }^{(0)}=0 \\
& N^{(0)}=E A w_{c}{ }^{(0)}, K^{(0)}=i_{p 0}{ }^{2} N^{(0)}
\end{aligned}
$$

となる。これらを式 (7.4) に代入すると

$$
\begin{aligned}
& M_{x}{ }^{\prime \prime}+\left\{N^{(0)}\left(u_{s}+y_{s} \varphi^{\prime}\right)\right\}^{\prime}=0 \cdots \cdots \cdots \cdots(7.10 \\
& M_{y}{ }^{\prime \prime}+\left\{N^{(0)}\left(v_{s}{ }^{\prime}-x_{s} \varphi^{\prime}\right)\right\}^{\prime}=0 \cdots \cdots \cdots \cdots(7.10 \mathrm{~b}) \\
& M_{\omega}{ }^{\prime \prime}+T_{s}{ }^{\prime}+\left\{N^{(0)}\left(y_{s} u_{s}^{\prime}-x_{s} \tau^{\prime}{ }^{\prime}\right)+K^{(0)} \varphi^{\prime}\right\}^{\prime} \\
& \quad+m_{t n}{ }^{(0)} \varphi=0 \cdots \cdots \cdots \cdots \cdots \cdots \cdots \cdots \cdots \cdots(7.10 \mathrm{c})
\end{aligned}
$$

このときの境界条件は, 式 (7.5) から

$$
\begin{aligned}
& u_{s}=0 \text { または } M_{x}{ }^{\prime}+N^{(0)}\left(u_{s}{ }^{\prime}+y_{s} \varphi^{\prime}\right)=0 \\
& u_{s}{ }^{\prime}=0 \text { または } M_{x}=0 \\
& r_{s}=0 \text { または } M_{y}{ }^{\prime}+N^{(0)}\left(r_{s}^{\prime}-x_{s} \varphi^{\prime}\right)=0 \\
& \tau_{s}^{\prime}=0 \text { または } M_{y}=0 \\
& (7.11 \mathrm{a} \sim \mathrm{d}) \\
& \varphi=0 \text { または } \\
& M_{w}{ }^{\prime}+T_{s}+N^{(0)}\left(y_{s} u_{s}{ }^{\prime}-x_{s} \tau{ }^{\prime}{ }^{\prime}\right) \\
& +K^{(0)} \varphi^{\prime}=-\bar{T}_{n}{ }^{(0)} \varphi \\
& \varphi^{\prime}=0 \text { または } M_{\omega}=0
\end{aligned}
$$

を得る。座屈時の断面力の変化分は, 式 (7.6) より

$$
M_{x}=-E I_{x x} u_{s}{ }^{\prime \prime}, M_{y}=-E I_{y y} v^{\prime \prime}{ }^{\prime \prime}
$$

$M_{\omega}=-E I_{\omega \omega} \varphi^{\prime \prime}, T_{s}=G J_{s} \varphi^{\prime} \cdots \cdots \cdots(7.12 \mathrm{c}, \mathrm{d})$

$\tilde{w}_{c}^{\prime}=w_{c}^{\prime}+\left\{u_{s}^{(0) \prime}+\varphi^{(0) \prime}\left(y_{s} \cos \varphi^{(0)}+x_{s}\right.\right.$ 
式（7.12）亲（7.10）に代入すると, 变位表示した座 屈の支配方程式として次式を得る。

$$
\begin{aligned}
& -\left(E I_{x x} u_{s}^{\prime \prime}\right)^{\prime \prime}+\left\{N^{(0)}\left(u_{s}{ }^{\prime}+y_{s} \varphi^{\prime}\right)\right\}^{\prime}=0 \\
& -\left(E I_{y y} \tau^{\prime} s^{\prime \prime}\right)^{\prime \prime}+\left\{N^{(0)}\left(v_{s}{ }^{\prime}-x_{s} \varphi^{\prime}\right)\right\}^{\prime}=0 \\
& -\left(E I_{\omega \omega} \varphi^{\prime \prime}\right)^{\prime \prime}+\left(G J_{s} \varphi^{\prime}\right)^{\prime} \\
& +\left\{N^{(0)}\left(y_{s} u_{s}{ }^{\prime}-x_{s} v^{\prime}{ }^{\prime}+i_{p 0}{ }^{2} \varphi^{\prime}\right)\right\}^{\prime}+m_{t n}{ }^{(0)} \varphi=0
\end{aligned}
$$

$(7.13 \mathrm{c})$

\section{（2）横座屈}

$y \approx$ 面内の荷重を受け，その面内でだけ変位する部材 妾考える。すなわち，部材軸に沿って分布する荷重と して $p_{y}{ }^{(0)}, p_{z}{ }^{(0)}, m_{y}{ }^{(0)}, m_{t n}{ }^{(0)}$ を受け, 部材の両端で $\bar{N}^{(0)}, \bar{V}_{y}{ }^{(0)}, \bar{M}_{y}{ }^{(0)}, \bar{T}_{n}{ }^{(0)}$ (部材端力は一般に両端で異 なった值をとる）を受け，変位 $w_{c}{ }^{(0)}, v_{s}{ }^{(0)}$ だけが生ず る場合につい一考える。有限変位のときに注，式 (4.2) が成立するように点 $C, S$ を断面上の特定点に選んだと しても, 式 (5.1) でわかるように一般に汢すべての変位 が連成する。したがって，ここで考えている荷重条件の もとで

$$
v_{s}^{(0)}=0, w_{c}^{(0)}=0, u_{s}^{(0)}=\varphi^{(0)}=0
$$

の解汸存在するためには，断面に条件が付加され

$$
x_{s}=0
$$

でなければならない。また，式 (7.14) の解が存在する ときには，式 (4.4) より

$$
M_{x}{ }^{(0)}=M_{\omega}{ }^{(0)}=T_{s}{ }^{(0)}=0
$$

となる。事実, 式 (7.15) の条件が存在すると, ここで 考えている荷重条件のもとでは, 式 (7.14)，(7.16）は 恒等的に式 $(5.1 \mathrm{~b}, \mathrm{~d})$ のつり合い式および $(3.5 \mathrm{~b}, \mathrm{c}$, $\mathrm{f}, \mathrm{g})$ の境界条件を満足し，この問題の解になっている ことがわかる。

式 (7.14)，(7.15)，(7.16) を式 (7.4) に代入すると 座屈の支配方程式として次式を得る。

$$
\begin{aligned}
& \left(M_{x}-M_{y}{ }^{(0)} \varphi\right)^{\prime \prime}+\left\{N^{(0)}\left(u_{s}{ }^{\prime}+y_{s} \varphi^{\prime}\right)\right\}^{\prime} \\
& -\left(m_{y}{ }^{(0)} \varphi\right)^{\prime}=0 \\
& M_{\omega}{ }^{\prime \prime}+T_{s}{ }^{\prime}+v_{s}{ }^{(0)} / 1 M_{x}-M_{y}{ }^{(0)} u_{s}{ }^{\prime \prime}-M_{y}{ }^{(0)} v_{s}{ }^{(0)} " \varphi \\
& +\left\{N^{(0)} y_{s}\left(u_{s}{ }^{\prime}+v_{s}{ }^{(0) \prime} \varphi\right)+K^{(0)} \varphi^{\prime}\right\}^{\prime} \\
& -N^{(0)} y_{s} v_{s}{ }^{(0)} \varphi^{\prime}+m_{t n}{ }^{(0)} \varphi \\
& +m_{y}{ }^{(0)}\left(u_{s}{ }^{\prime}+v^{\prime}{ }^{(0)}{ }^{(0)} \varphi\right)=0
\end{aligned}
$$

境界条件は, 式 (7.5) から

$$
\begin{aligned}
& u_{s}=0 \text { または } \\
& \left(M_{x}-M_{y}{ }^{(0)} \varphi\right)^{\prime}+N^{(0)}\left(u_{s}^{\prime}-y_{s} \varphi^{\prime}\right)=0 \\
& u_{s}{ }^{\prime}=0 \text { または } M_{x}-M_{y}{ }^{(0)} \varphi=-\bar{M}_{y}{ }^{(0)} \varphi \\
& \varphi=0 \text { または }
\end{aligned}
$$

$$
\begin{aligned}
& M_{\omega}{ }^{\prime}+T_{s}+N^{(0)} y_{s}\left(u_{s}{ }^{\prime}+v_{s}{ }^{(0) \prime} \varphi\right)+K^{(0)} \varphi^{\prime} \\
& =-\bar{T}_{n}{ }^{(0)} \varphi+\bar{M}_{y}{ }^{(0)}\left(u_{s}{ }^{\prime}+v_{s}{ }^{(0) \prime} \varphi\right)
\end{aligned}
$$$$
\varphi^{\prime}=0 \text { または } M_{\omega}=0
$$

次に, 断面力の変化分を求めると

$$
\begin{aligned}
& M_{x}=-E I_{x x}\left(u_{s}^{\prime \prime}+v_{s}^{(0) " \varphi)}\right. \\
& M_{\omega}=-E I_{\omega \omega} \varphi^{\prime \prime} \\
& T_{s}=G J_{s} \varphi^{\prime}
\end{aligned}
$$

式 (7.19) を式 (7.17) 沪代入すると, 変位表示した 座屈の支配方程式上して次式を得る。

$$
\begin{aligned}
& -\left[E I_{x x}\left\{u_{s}^{\prime \prime}-\left(r_{s}^{(0) "}+\frac{M_{y}{ }^{(0)}}{E I_{x x}}\right) \varphi\right\}\right]^{\prime \prime} \\
& +\left\{N^{(0)}\left(u_{s}{ }^{\prime}+y_{s} \varphi^{\prime}\right)\right\}^{\prime}-\left(m_{y}{ }^{(0)} \varphi\right)^{\prime}=0 \\
& -\left(E I_{\omega \omega} \varphi^{\prime \prime}\right)^{\prime \prime}+\left(G J_{s} \varphi^{\prime}\right)^{\prime}-\left(v_{s}{ }^{(0) \prime \prime}+\frac{M_{y^{(0)}}}{E I_{x \cdot x}}\right) \\
& \text { - } E I_{x x}\left(u_{s}^{\prime \prime}+\tau^{\prime(0) \prime} \varphi\right)+\left\{N^{(0)} y_{s}\left(u_{s}^{\prime}+\tau_{s}{ }^{(0) \prime} \varphi\right)\right. \\
& \left.+\left(i_{p 0}{ }^{2} N^{(0)}-i_{p y} . M_{y}{ }^{(0)}\right) \varphi^{\prime}\right\}^{\prime}-N^{(0)} y_{s} \tau_{s}{ }^{(0) \prime} \varphi^{\prime} \\
& +m_{t n^{(0)}} \varphi \div m_{y}{ }^{(0)}\left(u_{s}{ }^{\prime}+v_{s}{ }^{(0)} \varphi\right)=0
\end{aligned}
$$

ただし，式 (4.8)より

$$
K^{(0)}=i_{p 0}^{2} N^{(0)}+i_{p y} \cdot M_{y^{(0)}}
$$

\section{8. 変位の小さい場合の基本式}

実際構造物一の適用考考元と，変位に対寸る構造物 の供用限界があり，大き亦変位を扱うことはまれであ る。変位 $\varphi$ が小さいにき, $\cos \varphi, \sin \varphi$ を級数眼開する と

$$
\begin{aligned}
& \cos \varphi=1-\frac{1}{2} \varphi^{2}+\frac{1}{24} \varphi^{4}-\cdots \\
& \sin \varphi=\varphi-\frac{1}{6} \varphi^{3}+\frac{1}{120} \varphi^{5}-\cdots
\end{aligned}
$$

式 (8.1) 2. ６．章の基本式に代入し, 必要とする精 度に応じて高次項を省略することによって変位の小さい 場合の支配方程式が求まる。変位が微小であるとして, 変位の二次以上の項を無視すると, 式 (2.4), (2.24) は

$$
\begin{aligned}
& u=u_{s}-\left(y-y_{s}\right) \varphi \cdots \ldots \ldots . . . \\
& v=v_{s}+\left(x-x_{s}\right) \varphi \cdots \ldots \ldots . . . \\
& \tau=w_{c}-x u_{s}^{\prime}-y^{\prime} v_{s}{ }^{\prime}-\omega \varphi^{\prime}
\end{aligned}
$$

となる。断面力一変位の関倸证式 (4.4) から

$$
\begin{array}{r}
N=E A w_{c}{ }^{\prime}, M_{x}=-E I_{x x} u_{s}{ }^{\prime \prime}, M_{y}=-E I_{y y} v_{s}^{\prime \prime} \\
\cdots \cdots \cdots \cdots \cdots \cdots \cdots(8.3 \mathrm{a} \sim \mathrm{c}) \\
M_{\omega}=-E I_{\omega \omega} \varphi^{\prime \prime}, T_{s}=G J_{s} \varphi^{\prime} \cdots \cdots \cdots \cdots(8.3 \mathrm{~d}, \mathrm{e})
\end{array}
$$

となる。式 (5.1) からつり合い式は

$\left(E A w_{c}\right)^{\prime}=0$

$-\left(E I_{x x} u_{s}^{\prime \prime}\right)^{\prime \prime}-p_{x}-\dot{r} m_{x}^{\prime}=0$

$-\left(E I_{y y} v_{s}^{\prime \prime}\right)^{\prime \prime}+P_{y}+m_{y}{ }^{\prime}=0$ 


$$
-\left(E I_{\omega \omega} \varphi^{\prime \prime}\right)^{\prime \prime}+\left(G J_{s} \varphi^{\prime}\right)^{\prime}-m_{t}+m_{\omega}^{\prime}=0
$$

となる。式 (8.4) は従来の微小変位の一般式と一致す る。有限変位式の最低次のものとして三次以上の高次項 を無視すると，式 (2.4) より

$$
\begin{aligned}
& u=u_{s}-\left(y-y_{s}\right) \varphi-\frac{1}{2}\left(x-x_{s}\right) \varphi^{2} \\
& r=\tau^{\prime}+\left(x-x_{s}\right) \varphi-\frac{1}{2}\left(y-y_{s}\right) \varphi^{2}
\end{aligned}
$$

を得る。変位 $\xi, \eta$ および

$$
\begin{aligned}
& \xi=l u_{s}+m v_{s}+\rho_{s} \varphi-\frac{1}{2} \rho_{n} c^{2} \cdots \cdots \cdots \cdots \cdots(8.6 \\
& r=-m u_{s}+l v_{s}+\rho_{n} \varphi+\frac{1}{2} \rho_{s} \varphi^{2} \cdots \cdots \cdots \cdots(8.6 \\
& w^{\prime}=w_{c}-x\left(u_{s}^{\prime}+v_{s}^{\prime} \varphi\right)-y\left(\tau_{s}^{\prime}-u_{s}^{\prime} \varphi\right)-\omega \varphi^{\prime}
\end{aligned}
$$

となる。直ひずみ $\epsilon_{z}$ とせん断ひずみ $\gamma_{s z}$ については， 式 (2.26) 加次式を得る。

$$
\begin{aligned}
& \epsilon_{z}=r v_{c}{ }^{\prime}+\frac{1}{2}\left(i u_{s}{ }^{\prime 2}+v^{\prime}{ }^{\prime 2}\right)-\left(y_{s} u_{s}{ }^{\prime}-x_{s}{ }^{\prime}{ }^{\prime}{ }^{\prime}\right) \varphi^{\prime} \\
& -x\left(u_{s}^{\prime \prime}+v_{s}^{\prime \prime} \varphi\right)-y\left(\gamma_{s}^{\prime \prime}-u_{s}^{\prime \prime} \varphi\right)-\omega \varphi^{\prime \prime} \\
& \left.+\frac{1}{2}\left\{\left(x-x_{s}\right)^{2}+\left(y-y_{s}\right)^{2}\right\}\right\}^{\prime 2} \cdots \cdots(8.8 \mathrm{a}) \\
& \gamma_{s z}=\theta \varphi^{\prime}
\end{aligned}
$$

断面力は式 (4.4) から明らかなように, 变位の一次以上 の項からなる。また，荷重と断面力は等価な量と考えら れるので，荷重項も断面力と同様に変位の一次の項に相 当するとして取扱うと式 (3.4) のつり合い方程式は次の ようになる。

$$
\begin{aligned}
& N^{\prime}+q_{z}=0 \\
& \left(M_{x}-M_{y} \varphi\right)^{\prime \prime}+\left\{N\left(u_{s}^{\prime}+y_{s} \varphi^{\prime}\right)\right\}^{\prime}+p_{x} \\
& +\left(m_{x}-m_{y} \varphi\right)^{\prime}=0 \\
& \left(M_{y}+M_{x} \varphi\right)^{\prime \prime}+\left\{N\left(v_{s}{ }^{\prime}-x_{s}{ }^{\prime} \varphi^{\prime}\right)\right\}^{\prime}+p_{y} \\
& +\left(m_{y}+m_{x} \varphi\right)^{\prime}=0 \\
& M_{\omega}^{\prime \prime}-M_{y} u_{s}^{\prime \prime}+M_{x} v_{s}^{\prime \prime}+\left\{N\left(y_{s} u_{s}^{\prime}-x_{s} v_{s}^{\prime}\right)\right. \\
& \left.+K \varphi^{\prime}\right\}^{\prime}+T_{s}{ }^{\prime}+m_{t}+m_{t n} \varphi+m_{y}\left(u_{s}{ }^{\prime}+v_{s}{ }^{\prime} \varphi\right) \\
& -m_{x}\left(v_{s}{ }^{\prime}-u_{s}{ }^{\prime} \varphi\right)+m_{\omega}{ }^{\prime}=0
\end{aligned}
$$

式 (3.5) の境界条件は, 次のように表わされる。

$$
\begin{aligned}
w_{c} & =C_{1} \text { または } \bar{N}=N \cdots \cdots \cdots \cdots \cdots \cdots \cdots(8.10 \\
u_{s} & =C_{2} \text { または } \\
\bar{V}_{x} & =\left(M_{x}-M_{y} \varphi\right)^{\prime}+N\left(u_{s}^{\prime}+y_{s} \varphi^{\prime}\right)+\left(m_{x}\right. \\
& \left.-m_{y} \varphi\right) \cdots \cdots \cdots \cdots \cdots \cdots \cdots \cdots \cdots \cdots \cdots \cdots \cdots(8 . \cdots \cdots \cdots \cdots \cdots \cdots \cdots \cdots \cdots \\
u_{s}{ }^{\prime} & =C_{3} \text { または } \bar{M}_{x}-\bar{M}_{y} \varphi=M_{x}-M_{y} \varphi
\end{aligned}
$$

$v_{s}=C_{4}$ または

$$
\bar{V}_{y}=\left(M_{y}+M_{x} \varphi\right)^{\prime}+N\left(\tilde{v}_{s}^{\prime}-x_{s} \varphi^{\prime}\right)
$$$$
+\left(m_{y}+m_{x} \varphi\right)
$$

$v_{s}^{\prime}=C_{5}$ または $\bar{M}_{y}+\bar{M}_{x \varphi}=M_{y}+M_{x} \varphi$

$$
\varphi=C_{6} \text { または }
$$$$
\bar{T}-\bar{T}_{n} \varphi+\bar{M}_{x}\left(u_{s}^{\prime}-v_{s}^{\prime} \varphi\right)=M_{o}{ }^{\prime}+T_{s}+N^{\prime}
$$$$
\left(y_{s} u_{s}^{\prime}-x_{s} v_{s}^{\prime}\right)+K \varphi^{\prime}+m_{\omega}
$$

$$
\varphi^{\prime}=C_{7} \text { または } \bar{M}_{\omega}=M_{\omega}
$$

式 (4.5) は

$$
\begin{array}{r}
\tilde{w}_{c}^{\prime}=w_{c}{ }^{\prime}+\frac{1}{2}\left(u_{s}^{\prime 2}+\tau_{s}^{\prime 2}\right)+\left(y_{s} u_{s}^{\prime}-x_{s} \tau_{s}^{\prime}\right) \varphi^{\prime} \\
\cdots \cdots \cdots \cdots \cdots \cdots \cdots(8.11 \mathrm{a}) \\
\tilde{u}_{s}^{\prime \prime}=u_{s}^{\prime \prime}+\tau_{s}^{\prime \prime} \varphi, \tilde{v}_{s}^{\prime \prime}=v_{s}^{\prime \prime}-u_{s}^{\prime \prime} \varphi \cdots(8.11 \mathrm{~b}, \mathrm{c})
\end{array}
$$

となる。式 (8.11) を用いると式 (4.4) の断酒力と変位 の関係はそのまま成り立つ。この断面力一変位の関倸を 式 (8.9) に代入し, 三次以上の高次項を無視方吕之, 次 の変位表示のつり合い式を得る。

$$
\begin{aligned}
& \left(E A \tilde{w}_{c}{ }^{\prime}+\frac{1}{2} E I_{p_{0}} \varphi^{\prime 2}\right)^{\prime}=0 \\
& -\left(E I_{x x} \tilde{u}_{s}^{\prime \prime}-\frac{1}{2} E I_{p x} \varphi^{\prime 2}-E I_{y y} i_{s}^{\prime \prime} \varphi\right)^{\prime \prime} \\
& +\left\{E A w_{c}^{\prime}\left(u_{s}^{\prime}+y_{s} \varphi^{\prime}\right)\right\}^{\prime} \\
& +p_{x}+\left(m_{x}-m_{y} \varphi\right)^{\prime}=0 \\
& -\left(E I_{y y} \tilde{v}_{s}^{\prime \prime}-\frac{1}{2} E I_{p y} \varphi^{\prime 2}+E I_{x x} u_{s}^{\prime \prime} \varphi\right)^{\prime \prime} \\
& +\left\{E A w_{c}^{\prime}\left(v_{s}^{\prime}-x_{s} \varphi^{\prime}\right)\right\}+p_{y}+\left(m_{y}+m_{x} \varphi\right)^{\prime}=0 \\
& \cdot(8.12 \mathrm{c}) \\
& -\left(E I_{\omega \omega} \varphi^{\prime \prime}-\frac{1}{2} E I_{p \omega} \varphi^{\prime 2}\right)^{\prime \prime}-E\left(I_{x x}-I_{y y}\right) u_{s}^{\prime \prime} i_{s}^{\prime \prime} \\
& +\left\{E A w_{c}\left(y_{s} u_{s}{ }^{\prime}-x_{s} \tau^{\prime}{ }^{\prime}\right)+\left(E I_{p 0} w_{c}^{\prime}\right.\right. \\
& \left.\left.-E I_{p x} u_{s}^{\prime \prime}-E I_{p y} \tau_{s}^{\prime \prime}-E I_{p \omega} \varphi^{\prime \prime}\right) \varphi^{\prime}\right\}^{\prime} \\
& +\left(G J_{s} \varphi^{\prime}\right)^{\prime}+m_{t}+m_{t n} \varphi+m_{y}\left(u_{s}^{\prime}+\tau^{\prime}{ }^{\prime} \varphi\right) \\
& -m_{x}\left(v_{s}^{\prime}-u_{s}^{\prime} \varphi\right)+m_{w^{\prime}}=0
\end{aligned}
$$

\section{9. 考察}

\section{（1）棒理論におけるひずみと応力}

三次元の変位場を一次元の棒理論の場に置き換えるた めに, 式 (2.3) で一般の棒理論で用いられていると同じ ように， $\epsilon_{x}=\epsilon_{y}=r_{x y}=0$ を仮定した。しかし，このこ とは必ずしも $\epsilon_{x}$ や $\epsilon_{y}$ が $\epsilon_{z}$ に比べ無視しうるほぼ小 さいことを意味しない。実際には多くの棒部材は一軸応 力状態にあるとみなせ, $\epsilon_{x}, \epsilon_{y}$ は $-\nu \epsilon_{z}$ に近い值になっ ていると考えられる。従来から棒理論では一軸応力を 仮定しながら，同時にこれと矛盾する式 (2.3) の仮 定が用いられている。直応力一直ひずみの関倸として Kollbrunner, Hajdin ${ }^{7)}$ は, $s$ 方向のひずみ $\epsilon_{s}=0, n$ 方 向のひずみ $\epsilon_{n} \neq 0, n$ 方向の応力 $\sigma_{n}=0$ を仮定し

$$
\sigma_{z}=\frac{E}{1-\nu^{2}} \epsilon_{z}
$$

を用いている。Vlasov は式 (9.1) において, $\nu^{2}$ は 1 に 比べて小さいとしてこの項を無視し, 式 (4.1 a) を用い 
ている。しかし，ここでは棒理論そのものは数多くの実 験的検証を受けてきていることを考えて，従来から棒理 論で暗黙のらちに仮定されてきた式 (2.3)，(4.1 a)の 関係式をそのまま仮定として用いることにした。

式 (3.1)の仮想仕事の原理において, 式 (2.3) を理由 に $s n$ 面内の直応力による仮想仕事をおとしたが，実際 には断面内の直応力は, 棒軸方向の直応力に比べ十分無 視できるような一軸応力状態に近いためである，と考え たほうが実情に近い。いずれにしろ，結果に影響しない ので理論上の仮定の統一をはかるため, 式 (2.3) を理由 とした。

\section{（2）変 位 場}

仮想仕事の原理によってっり合い式を求めるときに は，変位場の仮定に十分注意を払う必要のあることは， はじめに述べた。ここでは, 従来から棒理論で用いられ てきた仮定のみを用いて, 式 (2.4), (2.24) の変位場を 求めた。Roik, Carl, Lindner ${ }^{2)}$ は幾何学的考察によ。 て式 (8.5)，(8.7) の変位場にほぼ一致する結果を得て いる。ただ，式 (8.7) のそりを表わす項に本報告との差 がみられる。すなわち, 本報告では, 式 (2.24) でそり は $\omega \varphi^{\prime}$ であるのに対して, Roik, Carl, Lindner の結 果を本報告の記号で記すと, $\omega\left(\varphi^{\prime}+u_{s}{ }^{\prime} r_{s}^{\prime \prime}-u_{s}^{\prime \prime} v_{s}{ }^{\prime}\right)$ 之 なっている。

坂井 ${ }^{3)}$ は, 微小変位理論で用いられている変位, 式 （8.2）を仮定し，この変位をも之に有限变位のひずみ一 変位関係からひずみを求めている。このように微小变位 理論による変位場を用いた上で，有限変位のひずみ一変 位関係を用いているため，一般の棒理論で仮定されてい る，断面の剛体変位とせん断ひずみに対するオイラー・ ベルヌイの仮定を表わす式 (2.3)，(2.13）が満足されな くなっている。坂井の結果が Vlasov ${ }^{1)}$ や Roik, Carl, Lindner $^{2)} お よ ひ ゙$ 本報告の結果と差の生じたのは用いた 変位場の差に起因する。その差については後に示す。

\section{（3）有限変位の応力解析}

\section{a）大きなねじりを受ける棒}

微小変位の問題では, 式 (4.2) を満たすように点 $C$, $S$ を断面上の特定点に選び $\Omega_{c}$ *を決定すると, 式 (8.4) から軸方向, 曲げおよびねじりの変位成分を独立に扱え ることがわかる。これに対して有限変位の問題では, 式 (5.1) あるいは式 (8.12) からわかるように一般にはす ベての変位成分が連成する。これが有限変位の問題を困 難にしている一因でもあるが，断面形状や荷重条件を限 定すると問題を比較的簡単に扱える場合があり，その一 例としてねじり荷重が作用し棒部材にねじり変位のみが 生じている場合を取り上げる。すなわち, 変位は次式で
与えられるとする。

$$
u_{s}=v_{s}=0, \varphi \neq 0 \text {. }
$$

式 (9.2) が式 (5.1b,c) のつり合い式および式 (3.5 b

〜e）の境界条件を満たす解であるためには，

$$
x_{s}=y_{s}=0, I_{p x}=I_{p y}=0
$$

でなければならない。式 (9.3) は二軸対称断面や点対称 の断面であれば成立する。式 (9.3) を満たす断面の場合 には, 式 $(5.1 \mathrm{~d})$ からつり合い式として

$$
\begin{aligned}
& -\left(E I_{\omega \omega} \varphi^{\prime \prime}-\frac{1}{2} E I_{p \omega} \varphi^{\prime 2}\right) \\
& +\left\{\left(E I_{p_{0}} w_{c}^{\prime}-E I_{p \omega} \varphi^{\prime \prime}+\frac{1}{2} E I_{p p} \varphi^{\prime 2}\right) \varphi^{\prime}\right\}^{\prime} \\
& +G J_{s} \varphi^{\prime \prime}=m_{t} \cos \varphi+m_{t n} \sin \varphi \cdots \cdots \cdots \cdots(9
\end{aligned}
$$

を得る。式 $(4.4 \mathrm{a})$ および $(4.5 \mathrm{a})$ から軸力と変位の関 係は,

$$
\mathrm{V}=E A w_{c}^{\prime}+\frac{1}{2} E I_{p_{0}} \varphi^{\prime 2}
$$

となる。式 (9.4)，(9.5）加 w融去去すと次式 を得る。

$$
\begin{aligned}
& \left\{-E I_{\omega \omega} \varphi^{\prime \prime \prime}+\frac{1}{2} E\left(I_{p p}-\begin{array}{c}
I_{p 0^{2}}{ }^{2} \\
A
\end{array}\right) \varphi^{\prime 3}\right. \\
& \left.\quad+\left(G J_{s}+N \frac{I_{p 0}}{A}\right) \varphi^{\prime}\right\}^{\prime}=m_{t} \cos \varphi+m_{t n} \sin \varphi
\end{aligned}
$$

Kappus $^{8)}$ は， 円断面や薄い平板が大きい単純ねじり （ $\varphi^{\prime}=$ 一定）を受ける場合について，つり合い式を求的 ている。Timoshenko9) はさらに軸方向力を考虑し, 薄 い平板に対し具体的に適用している。式 (9.6) で $\varphi^{\prime}=$ 一定とすると Kappus, Timoshenko の結果と一致す る。島田 ${ }^{(0)}$ は, そり抵抗も含めたさらに一般的な場合一 の抬張を試みている。その中で, 大きなねじりによった 生ずる $\sigma_{z}$ を,

$$
\sigma_{z}=E \varphi^{\prime 2}
$$

と表わしている。これに対して Kappus, Timoshenko および本報告では，

$$
\sigma_{z}=\frac{1}{2} E \varphi^{\prime 2}
$$

であり, 島田の求めたつり合い式は, 式 (9.6) の左辺第 二項の係数 $1 / 2$ を 1 で置き換えたものよなっている。島 田はそのつり合い式を $\mathrm{H}$ ビーム, さらに溥形鋼部材に も適用し，実験も行っているが，溝形鋼では式 (9.3)が 成立せず，したがって，式 (9.6) に相当する式を溝形鋼 部材に適用することには疑問が残る。

大きなねじれを受ける場合には，式 $(4.4 \mathrm{e})$ で示され る断面力 $K$ が生ずる。これは有限変位を考えたときに のみ現われる断面力である。これによる断面上での $\sigma_{z}$ の分布は $\rho_{s n}{ }^{2}$ に比例する成分をもつ。そのため 図一2 (b) に示すように， $\sigma_{z}$ は板厚方向に放物線形の分布を する。これはねじりに伴って回転の中心から遠い線素ほ 
ど大きいスパイラル状の曲線を描くため, 線素間に長さ の差を生ずることによるものである。

\section{b) 一般のつり合いの微分方程式}

式 (3.4) は断面力で表わしたつり合い方程式を示す。 この式で三次以上の高次項を無視した結果が式 (8.9) で ある。この式において変位と積の形で表われる断面力を 既知として扱い，残りの断面力を微小変位のもとで得ら れる線形な断面力と変位の関係, 式 (8.3) を用いて変位 で表現すれば，つり合い式は線形化され荷重条件の違い を除いて Vlasov'1), Roik, Carl, Lindner ${ }^{2)}$ らの求めた つり合い式と一致する。しかしながら，この線形化が妥 当である保証は一般には存在しない。後に座屈の項で述 べるが，Vlasov の求めた座屈支配方程式と本報告の基 本式に差が生ずるが，この差は，ここに指摘した線形化 によるものである。

坂井 ${ }^{3)}$ は, Vlasov や Roik, Carl, Lindner 々同様の 線形化有限変位理論を報告しているが，断面内の点 $S$ $\left(x_{s}, y_{s}\right)$ に関する㸚じりのつり合式の荷重項で，そ れら二つの報告および本報告の結果と違いがみられる。 このことは坂井自身, Vlasov との比較で指摘している。 坂井の結果を本報告の記号を用いて表わすと, 分布荷重 $p_{x d}, p_{y d}$ が, 断面が $\varphi$ 回転したことによってつくりだ す付加的なねじりモーメント $\Delta m_{t}$ は

$$
\begin{aligned}
\Delta m_{t}= & \int_{A}\left[\left\{p_{x d}\left(x-x_{s}\right)+p_{y d}\left(y-y_{s}\right)\right\}\right. \\
& \left.-\left(p_{x d} i_{p x}+p_{y d} i_{p y}\right)\right] \sin \varphi d A \cdots \cdots
\end{aligned}
$$

となる。ただし, 坂井は, $\sin \varphi=\varphi$ としている。これ に対し，本報告, Vlasov および Roik, Carl, Lindner の結果は,

$$
\begin{aligned}
\Delta m_{t} & =\int_{A}\left\{p_{x d}\left(x-x_{s}\right)+p_{y d}\left(y-y_{s}\right)\right\} \sin \varphi d A \\
& =-m_{t n} \sin \varphi \cdots \cdots \cdots \cdots \cdots \cdots \cdots \cdots \cdots \cdots \cdots(9.10)
\end{aligned}
$$

である。式 (9.10) は $p_{x d}, p_{y d}$ が点 $S$ のまわりにつ くる分布秝じりモーメントを表わすのに対し式 (9.9) は それ以外の点で分布和り゙荷重の增分 $\Delta m_{t}$ を求めたこ とを表わしており，明らかに不都合である。

\section{（4）座屈}

式 (7.2)，(7.3）から安定限界状態での支配方程式と して, 式 (7.4) (7.7) を得た。この計算過程は第二変 分を 0 とおいたのと等価である。他者の結果との比較の ため, 座屈前にはねじり変形を受けず, $\varphi^{(0)}=0$, さらに 境界条件から座屈後の軸力の変化分は 0 である場合を考 えると，式 (7.4) は次のようになる。

$$
\begin{aligned}
& \left(M_{x}-M_{y}{ }^{(0)} \varphi\right)^{\prime \prime}+\left\{N^{(0)}\left(u_{s}{ }^{\prime}+y_{s} \varphi^{\prime}\right)\right\}^{\prime} \\
& -\left(m_{y}{ }^{(0)} \varphi\right)^{\prime}=0 \\
& \left(M_{y}+M_{x}^{(0)} \varphi\right)^{\prime \prime}+\left\{N^{(0)}\left(v_{s}^{\prime}-x_{s} \varphi^{\prime}\right)\right\}^{\prime} \\
& +\left(m_{x}{ }^{(0)} \varphi\right)^{\prime}=0
\end{aligned}
$$

$$
\begin{aligned}
& \left.M_{\omega}^{\prime \prime}+T_{s}{ }^{\prime}+v_{s}{ }^{(0)} / M_{x}-u_{s}{ }^{(0)}\right), M_{y}-M_{y}{ }^{(0)} u_{s}{ }^{\prime \prime} \mid \\
& +M_{x}{ }^{(0)} v_{s}{ }^{\prime \prime}-\left(M_{x}{ }^{(0)} u_{s}{ }^{(0) \prime}+M_{y}{ }^{(0)} v_{s}{ }^{(0) \prime \prime}\right) \varphi \\
& +\left[N^{(0)}\left\{y_{s} u_{s}^{\prime}-x_{s} v_{s}^{\prime}+\left(x_{s} u_{s}^{(0) \prime}+y_{s} v_{s}^{(0) \prime}\right) \varphi\right\}\right. \\
& \left.+K^{(0)} \varphi^{\prime}\right]^{\prime \prime}-N^{(0)}\left(x_{s} u_{s}^{(0) \prime}+y_{s} v_{s}^{(0) \prime}\right) \varphi^{\prime} \\
& +m_{t n}{ }^{(0)} \varphi+m_{x}{ }^{(0)}\left(v_{s}{ }^{\prime}-u_{s}{ }^{(0)} \varphi\right) \\
& +m_{y}{ }^{(0)}\left(u_{s}{ }^{\prime}+v_{s}{ }^{(0)} \varphi\right)=0
\end{aligned}
$$

このとき断面力は, 式 (7.6), (7.7) から,

$$
\left.\begin{array}{l}
M_{x}=-E I_{x x}\left(u_{s}{ }^{\prime \prime}+v_{s}{ }^{(0) "} \varphi\right) \\
M_{y}=-E I_{y y}\left(v_{s}^{\prime \prime}-u_{s}{ }^{(0) "} \varphi\right) \\
M_{\omega}=-E I_{\omega \omega} \varphi^{\prime \prime}, T_{s}=G J_{s} \varphi^{\prime}
\end{array}\right\}
$$

断面力 $K^{(0)}$ は, 式 (4.8) から,

$$
K^{(0)}=i_{p 0}{ }^{2} N^{(0)}+i_{p x} M_{x}{ }^{(0)}+i_{p y} M_{y}{ }^{(0)} \cdots
$$

となる。

式 (9.11) において, 右屃に（（）号付した座屈前 の変位をすべて 0 とすれば，その結果の式は Vlasov， Roik, Carl, Lindner の結果と一致する。それゆえ, 座 屈前に軸方向変位以外の変位を伴わ交い中心圧縮材の座 屈の支配方程式は，Vlasov や Roik, Carl, Lindner お よび坂井の結果と本報告の結果とは一致するが，はりや 柱一はりの横座屈のように一軸面内に曲汭と圧縮を受け たのち, 横方向へ座屈する場合の支配方程式では, 本報 告の結果には, 座屈前の変位項が含まれているのに対 し, 他の結果では含まれていない。このように後者で座 屈前の変位項が失われているのは, 応力場や变位場をは じめに線形化したうえでつり合い式を求めたことによ る。前記（3）の b) 項で述べたように坂井のねじりの つり合い式では，この変位項のほかに荷重項にも差があ る。式 $(9.11 \mathrm{c})$ 中の $\left(M_{x}{ }^{(0)} u_{s}{ }^{(0) \prime \prime}+M_{y}{ }^{(0)} v_{s}{ }^{(0) \prime \prime}\right) \varphi$ のよ うに（0）系の二次項を係数として含声項は, Nishino, Kasemset, Lee $\left.{ }^{6}\right)$ の結果には含まれていない。Nishino, Kasemset, Lee の報告では, $\sin \varphi, \cos \varphi$ を展開し変位 の二次項までを考慮した式 (8.5)，(8.6)，(8.7) を用い たためにこの項が落ちている。 $\sin \varphi, \cos \varphi$ を展開した 変位場を用いるときにこの項が含ま礼るた的には，変位 の三次項までとる必要がある。

座屈前の応力状態での変位項の影響をみるため, 二軸 対称な断面をもつ両端単純支持の直線ばりが荷重とし て, 部材両端で等曲げ $\bar{M}_{y}{ }^{(0)}$ のみを受ける場合を考え る。この条件のもとで式 (5.1) のつり合い式拉よび式 (3.5) の境界条件を満足する解㳄次のように求まる。

$$
\begin{aligned}
& u_{s}^{(0)}=0, \varphi^{(0)}=0, v_{s}^{(0) \prime \prime}=-\frac{\bar{M}_{y}{ }^{(0)}}{E I_{y y}}, \\
& w_{c}{ }^{(0) \prime}=-\frac{1}{2}\left(v_{s}{ }^{(0) \prime}\right)^{2} \cdots \cdots \cdots \cdots \cdots \cdots(9.14 \mathrm{a} \sim \mathrm{d})
\end{aligned}
$$

式 (9.14) を式 (4.4a) に代入すると

$$
\mathrm{N}^{(0)}=0
$$

式 $(9.14 \mathrm{c}),(9.15)$ を式 (7.20) に代入し， $u_{s}$ を消 去すると, 横座屈の支配方程式として 


$$
E I_{\omega \alpha} \varphi^{\mathbb{N}}-G J_{s} \varphi^{\prime \prime}+\frac{\bar{M}_{y}{ }^{(0) 2}}{E}\left(\frac{1}{I_{x x}}-\frac{1}{I_{y y}}\right) \varphi=0
$$

を得る。この式の固有值から, 次の座屈モーメントが求 まる。

$$
\bar{M}_{y}{ }^{(0)}=\frac{\pi}{L} \sqrt{E\left(\frac{I_{x x} I_{y y}}{I_{y y}-I_{x x}}\right) G J_{s}\left(1+\frac{\pi^{2} E I_{w \omega}}{G J_{s} L^{2}}\right)}
$$

ここに，Lははりの支間長である。この解は Nishino， Kasemset, Lee ${ }^{6)}$ の結果と一致する。これに対して Vlasov, Roik, Carl, Lindner あるいは坂井の支配方程 式から求まる結果は, 上式で $\left(I_{x x} I_{y y}\right) /\left(I_{y y}-I_{x x}\right)$ を $I_{x x}$ に置き換えたものとなり，これまで一般に用いられ てきた解 ${ }^{11)}$ と一致する。式 (7.20) において $v_{s}^{(0) "=0}$ とすると後者の解が求まることから，この差は座屈前の 変位を考慮するかどらかに起因することがわかる。

式 (9.17) によれば, $I_{x x}<I_{y y}$ のとき，すなわち， 弱軸まわりに曲げをかけた場合には座屈は起こり得ない ことになり，たとえばIビームを考えれば直感的にも合 理的な解であることがわかる。これに対して座屈前の変 形を考えないときの解 ${ }^{11}$ では, $I_{x x}, I_{y y}$ の大きさにかか わらず, 端部での曲げモーメントが特定の值になると横 座屈することになる。Trahair, Woolcock ${ }^{5)}$ が求めた解 と式 (9.17) の間には差がみられるが, 前者の解にも $\left(I_{x x} I_{y y}\right) /\left(I_{y y}-I_{x x}\right)$ の項が含まれており, 弱軸まわり に曲げ荷重が作用する場合に座屈しないという点では一 致する。

\section{0. 結語}

一次元，あるいは二次元場での変形ナる物体のつり合 い式を仮想仕事の原理から求めるとき, 変位場を仮定す ることが重要であり, 得られたつり合い式の精度はこの 変位場の仮定によって決まる。有限変位のひずみ成分に 棒理論で広く用いられている仮定, 少なわち, 断面は 変形しないという仮定と，せん断ひずみに関するオイ ラー・ベルヌイの仮定を適用し, 薄肉断面部材の一次元 の有限変位理論に対して妥当と思われる変位場を求め た。この変位場を用いて仮想仕事の原理から, 軸力, 曲 げモーメントね隹りモーメントを受ける場合のつり合 い式, 境界条件および断面力と変位の関係を求めた。

ここで得られた支配方程式は一般にエラスティカとよ ばれている大変形の問題を扱 5 ものではないが, 従来, 薄肉断面部材に関する有限変位理論として文献で報告さ れているよりも大きな変位を扱らことができるものであ る。変位が微小なとき, この支配方程式は薄肉断面部材 に対する微小変位理論と一致する。变位が少し大きく，
変位の二次の項までを考虑したとき，本報告で得た支配 方程式には Vlasov, Roik, Carl, Lindner や坂井らに よって得られた基本式に含まれていない項が含まれてお り, 変位の二次の微小項までを考えた有限変位理論とし て,より精度の高いものとなっていると考えられる。

謝辞 : 本研究は昭和 48 年度の文部省科学研究費 による研究の一部として行われたものである。

記 号

i) 座標

$(x, y, z)$ : 右手系直交直線座標

$x_{s}, y_{s}:$ 点 $S$ の $x, y$ 座標

$(s, n, z)$ : 板厚中心線に沿って $s$, そ礼と直交する 方向に $n$ を選んだ右手系直交曲線座標

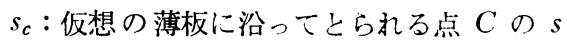
座標

$s_{1}$ : 板厚中心線上のある任意点の $s$ 座標

$C:(x, y, z)$ 座標の原点

$O: s$ 座標の原点

$S: u_{s}, v_{s}$ の定義される点

$l, m:$ 式 (2.5) で定義される方向余弦

ii）変位とひずみ

$u, \tau, v$ : 基準状態 (変形前) での $x, y, z$ 方向 への変位

$u_{s}, v_{s}$ : 点 $S$ の基準状態の $x, y$ 方向への変 位

$\tilde{w}_{c}{ }^{\prime}, \tilde{u}_{s}{ }^{\prime \prime}, \tilde{v}_{s}{ }^{\prime \prime}$ : 式 (4.5) で定義される量

$\xi, \eta:$ 基準状態の $s, n$ 方向への変位

$\left.\begin{array}{l}\epsilon_{x}, \epsilon_{y}, \epsilon_{z} \\ r_{x y}, r_{y z}, r_{z x}\end{array}\right\}:(x, y, z)$ 座標におけるひずみ成分

$\left.\begin{array}{l}\epsilon_{s}, \epsilon_{n}, \epsilon_{z} \\ \gamma_{s n}, \gamma_{n z}, \gamma_{s z}\end{array}\right\}:(s, n, z)$ 座標におけるひずみ成分

iii）断面上の長さ

$r^{*}:$ 板厚中心線の曲率半径

$t:$ 板厚

$\rho_{s}^{*}, \rho_{n}:$ 点 $S$ から板厚中心線の接線および法線に

下した垂線の長さ

$\rho_{s}: \rho_{s}{ }^{*}-n$

$\rho_{s n}: \sqrt{\rho_{s}^{2}+\rho_{n}^{2}}$

iv）変位, ひずみ, 応力などの断面上での分布形状を 表わす関数

$\theta:$ 式 (2.27) で定義される関数

$\omega:$ 式 (2.25) で定義される関数

$\Omega^{*}:$ 式 (2.21) で定義される関数

$\Omega_{c} *$ : 式 (2.23) で定義される関数 
$A_{s}, Q_{x}, Q_{y}, Q_{\omega}, Q_{p}:$ 式 (6.7) で定義される関数

v) 断 面量

$i_{p 0}, i_{p x}, i_{p y}, k_{p \omega}:$ 式 (4.9) で定義される量

$\left.\begin{array}{c}A \\ I_{x x}, I_{y y}, I_{\omega \omega} \\ I_{p 0}, I_{p x}, I_{p y}, I_{p \omega}, I_{p p}\end{array}\right\}:$ 式 (4.6) で定義される量

$\tilde{I}_{p p}:$ 式 (4.11) で定義される量

$J_{s}:$ 式 $(4.6 \mathrm{e})$ で定義される量

vi) 材料 定数

$$
\begin{aligned}
& E: \text { 弾性係数 } \\
& G: \text { せん断弾性係数 } \\
& \nu: \text { ポアソン比 }
\end{aligned}
$$

vii）応力と断面力

$$
q_{1}:\left(\tau_{s z}{ }^{*} t\right)_{s=s 1}, s=s_{1} \text { 点のせん断流 }
$$

$\sigma_{z}, \tau_{s z}, \tau_{n z}:$ 直応力とせん断応力

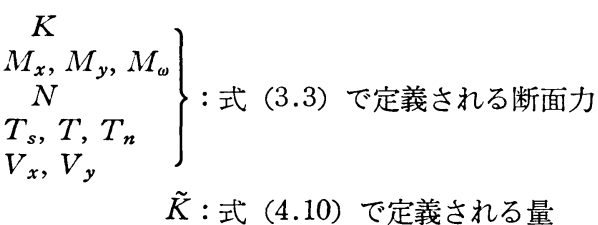

viii） 部材軸に沿って分布する外力

$p_{x d}, p_{y d}, p_{z d}: x, y, z$ 方向に向く単位体積あたりの 分布外力

$\tilde{p}_{z d}:$ 式 (6.3) で定義される変形後の部材軸

方向に向く単位体積あたりの分布外力

$p_{x}, p_{y}, p_{z}:$ 式 (3.3 k m) で定義される外力

$q_{p}:$ 式 $(6.7 \mathrm{f})$ で定義される量

$\left.\begin{array}{l}m_{x}, m_{y}, m_{\omega} \\ m_{t}, m_{t n}\end{array}\right\}:$ 式 $(3.3 \mathrm{n} \sim \mathrm{r})$ で定義される外力 ix) その他

上付 * : 板厚中心線上の值を示す。

上付 一: 部材端断面に作用する表面力を表わす。

上付 (0)：安定限界状態での諸量を表わす。

$$
\text { ( ) })^{\prime}: \frac{d()}{d z}
$$

$C_{1} \sim \mathrm{C}_{7}:$ 定数

$C(Z):$ 積分定数

\section{参 考 文 献}

1）Vlasov, V.Z.: 薄肉弾性ばりの理論，奥村他共訳，技報 堂, 1967

2) Roik, K., J. Carl und J. Lindner : Biegetorsionsprobleme gerader dünnwandiger Stabe, Verlag von Wilhelm Ernst und Sohn, 1972.

3）坂井藤一：薄肉開断面部材の弾性安定基礎方程式の統一 的誘導, 土木学会論文報告集, No. 221, pp. 1 15, 1974-1.

4) Washizu, K. : Variational Methods in Elasticity and Plasticity, Pergamon Press, 1968.

5) Trahair, N.S. and S.T. Woolcock : Effect of major axis curvature on I-beam stability, Journal of Engineering Mechanics Division, ASCE, Vol. 99, No. EM1, Proc. Paper 9548, pp. 85 98, Feb. 1973.

6) Nishino, F.,C. Kasemset and S.L. Lee : Variational formulation of stability problems for thin-walled members, Ingenier-Archiev, Band 43, Heft 1 pp. 58 $\sim 68,1973$.

7) Kollbrunner, C.F. und N. Hajdin : Dünnwandige Stäbe, Band 1, Springer-Verlag, 1972.

8) Kappus, R. : Zur Elastizitäts theorie endlicher Verschiebungen, II Teil, Z.A.M.M., Band. 19, 1939.

9) Timoshenko, S.P. : Strength of Materials, Part 2, D. van Nostrand, 1956.

10）島田静雄 : 薄肉部材の大きなねじれ，土木学会論文集， No. 94, pp. 1 5, 1963-6.

11) Timoshenko, S.P. and J.M. Gere : Theory of Elastic Stability, 2nd Ed. McGraw-Hill, 1961.

(1973.11.21 • 受付) 